\title{
İbn Haldûn'da Varlık ve İnsanın Evrimi
}

\section{Evolution of Existence and Man on Ibn Khaldun}

\author{
Dr. Öğr. Üyesi Murat ERTEN (iD) 1
}

\begin{abstract}
$\ddot{\mathbf{O} z}$
İbn Haldûn'un hiyerarşik varlık evreni, cansız varlıklardan melekler âlemine dek uzanan bir yapıdadır. Her varlık kuşağının en üst üyesi, kendisinden sonra gelen kuşağın en alt üyesine komşudur. Bu komşu varlıklar birbirlerinin evrimleşmiş halleridir. İnsan, hayvanlar âleminin en gelişmiş türüdür ve kendisinden önce gelen maymunun gelişmiş biçimidir. İnsanın en gelişmiş örnekleri olan veliler ve peygamberler, kendilerinden sonra gelen melekler âleminin en alt türlerine komşudurlar ve bu âleme yükselmek suretiyle ilham ve vahiy alırlar. Ancak insanın melekliğe evrimi fiziksel değil ruhsal ve akılsaldır. Ona göre insanın fiziksel olarak evrimleşmediğinin kanıtı, geçmiş toplumlardan kalan eserlerin bugünkülerle aynı temel prensiplere sahip olmasıdır. Böylece maymunun fiziksel ve aklî gelişimin sonucu olan insan, melekler âlemine yükselmek için yalnızca ruhsal yetilerini geliştirir. Evrim düşüncesinde İbn Haldûn, tümel bir yaklaşımla tüm varlıkları birbirine bağlar ve sürece maddî olmayan evreni de dâhil eder. Ancak insanın evrimini, tasavvufta ve On Akıl Teorisinde yer aldığı biçimiyle Allah'la ittisale dek yükseltmez ve vahiy alma ile keser. İbn Haldûn evrimin imkânını kimya, yöntemini tasavvufla belirler.
\end{abstract}

Anahtar Kelimeler: İslâm felsefesi, mukaddime, evrim, vahiy, kimya, tasavvuf, Darwin

Makale Türü: Derleme

Abstract
Ibn Khaldun's hierarchical universe of being runs from inanimate beings to world of angels. The highest
type of each generation of being is adjacent to the lowest type of the subsequent generation of being. These
neighbouring beings are evolved. Man is the most developed species of the animal kingdom and he is the
advanced form of the ape that preceded it. Walîs and prophets, the most advanced examples of human
beings, are adjacent to the lowest types of the angels and receive inspiration by rising to this realm.
However, the evolution of man into the world of angels is not physical but spiritual and mental. Evidence
that human beings have not evolved physically is that the works of past societies have the same conditions
of use as those of today. Thus, as the result of the physical and mental development of the ape, the human
being only develops his spiritual abilities to rise to the realm of angels. In his evolution thought Ibn Khaldun
connects all beings with a holistic approach and includes non-material universe. However, the evolution of
man does not ascend to alliance with Allah as it is in Sufism and the Ten Intellects Theory and interrupted
by revelation. Ibn Khaldun determines the possibility of evolution by chemistry and the method by Sufism.

Keywords: Philosophy of Islam, mukaddimah, evolution, revelation, chemistry, sufism, Darwin

Paper Type: Review

\footnotetext{
${ }^{1}$ Muğla Sıtkı Koçman Üniversitesi, Edebiyat Fakültesi, muraterten1 @gmail.com.

Atıf için (to cite): Erten, M. (2019). İbn Haldûn'da Varlık ve İnsanın Evrimi. Afyon Kocatepe Üniversitesi Sosyal Bilimler Dergisi, 21(Prof. Dr. Fuat Sezgin Özel Say1s1), 59-79.
} 


\section{Giriş}

Toplum yaşamının nihaî hedefi olan medeniyeti, gelişmeyi ve gelişirken çürümeyi bünyesinde aynı anda barındıran İbn Haldûn'un sosyal değişim veya umran teorisi, toplumsal evrim olarak da değerlendirilebilir (Arslan, 2002, 98; Özel, 1992, 118 vd). Asabiyye kavramı ile medeniyetin bedevî ve hadarî umran aşamaları sürecin sosyal duraklarıdır. Bunun bir parçası olarak insanın evrimi de; fiziksel, ruhsal ve zihinsel yönler barındırır. İbn Haldûn'un insanın evrimine ilişkin düşünceleri bu yönleriyle bazı araştırmacılar tarafından Charles Darwin'in habercisi sayılır (Hassan, 1977, 134). Buna karşın İbn Haldûn ile Darwin'in tam bir benzeşim içinde olduğunu söylemek güçtür. Güncel tartışmalara konu edilen İbn Haldûn benzer şekilde sosyal teorisi bakımından Montesquieu ve Machiavelli, iktisat düşüncesi bakımından Ricardo ve Malthus gibi başka bazı Batılı düşünürlerle de karşılaştırılsa da (Sezgin, 2008, C.I, 63; Tomar, 2006, 20) çalışmamızda biz yalnızca, Mukaddime' de çeşitli başlıklar halinde bulunan insanın ve o arada diğer varlıkların evrimine ilişkin düşünceleri bir araya getirdik. Bu bağlamda Darwin'in evrim teorisiyle de temel bazı konularda karşılaştırmasını yaptık.

Başlangıçta organik değişim anlamında kullanılan evrim/evolution kavramı daha sonra bildiğimiz şekliyle 'uzun bir olaylar dizisinin sırasıyla birbirini izlemesi, basitten karmaşığa doğru sıralı açılma ve ilkel olandan olgun ve eksiksiz olana doğru gelişme süreci' anlamlarında kullanılmıştır. $\mathrm{Bu}$ anlam, belli belirsiz ve örtülü mânâda tercihli bir ilerleme anlamını da içerir. Dolayısıyla evrimin bir amacı olmadığını ve maddesel/natural bir süreç olduğunu düşünen Charles Darwin (1809-1882), içerdiği bu anlamdan ötürü kavramı (1838'de yazıldığ 1 halde 1859 'da yayımlanan) Origin of Species/Türlerin Kökeni'nde kullanmamıştır. Darwin'in de bir parçası olduğu 19. Yüzyıl; dinî, siyasal ve bilimsel laiklik ile siyasî ve iktisadî hayat kavgası ilkeleri üzerinde yükselmekte olan bir çağdır. Toplum, geneli itibariyle pozitivist bir bilim, sosyalist bir siyaset anlayışına sahiptir. Bu itibarla daha önce de bazı yazarlar tarafından (Ricardo (1772-1823) ve Malthus (1776-1865) tarafindan iktisadî, Proudhon (1809-1865) tarafindan sosyoekonomik, Mendel (1822-1884) tarafindan kalıtım kanunlarl ve Lamarck (1744-1829) tarafindan kazanılmış karakterlerin aktarımı gibi) çeşitli anlamlarda dile getirilmiş olan evrim kuramı; o dönemde Darwin'le kısa zamanda yayılmış ve kitlelere mal olmuştur. (Bayrakdar, 2001, 13).

Evrim, terim olarak, esas itibariyle gelişmeyi ve değişmeyi ifade eder. Bu değişme veya gelişme, ister içten dışa doğru, dışsal etkenlerden bağımsız olsun, ister başlangıçta belirsiz bir biçimde bulunan bir ilkenin, yavaş yavaş kendini gerçekleştirip ortaya çıkması olsun, isterse de bir amaca doğru adım adım ilerlemeyi içersin. Evrimin Darwinci anlamında ise bir anlam ve bir ereğe yönelmişlik başka deyişle iradî bir yönelim kastedilmeksizin gerçekleşen değişim ifade edilir. Kavramın Nietzsche ve Bergson'da kazandığ 1 derinlik, bulucu, sınayıcı, yeniyi yaratıcı ve gelecekteki bir amaca yönelmiş, akılsal bir oluş ve ilerleme süreci işaret edilir. Lamarc ve Darwin'de türlerin birbirlerine dönüşümü, doğal bir türeyiştir ve Spencer'ın ileri sürmüş olduğu düşüncenin geliştirilmiş bir biçimidir. Buna göre evrim yasası cansızlardan düşünceye, insanîtoplumsal kurumlara değin her gerçek olana egemendir ve hem insan zihninin hayvanlarınkine üstünlüğü hem de ahlâk bilincinin ortaya çıkışı, evrimsel dönüşümün ürünüdür. (Akarsu, 1975, 71.) İnsanın evrimi konusunda ise bilim adamları dâhil çoğu kimse, azar azar gerçekleşen bir değişim süreci sonucunda hayvanların meydana gelmesi ve değişmekte olan bu hayvanlardan birinin insanın kökenini oluşturması, tek hücreli varlıktan insana dek uzayan uzun bir ilerleme, yükselme ve gelişme sürecini anlamaktadır. Bu değişiklik de, herhalde Darwin'in türeyiş anlayışına vurulmuş en ağır yanlış anlama darbesi olsa gerektir (Gould, 2002, 19 vd).

Evrim düşüncesini, ilk değişimin mecraını su, kök canlıyı ise balık olarak kabul eden Anaksimandros'a (M.Ö.610-547) değin geri götürmek mümkünse de (Arslan, 2006, 104), hem Pre-Sokratiklerde yer alan bu düşüncelerden evrim düşüncesine ulaşmak güçtür, hem de Metafizik'te Aristoteles'in türlerin sabitliğinden bahsettiği hatırlandığında, evrim düşüncesinin köklerinin Antik Yunanda bulunduğu iddiası tartışmaya açıtır. (Bayrakdar, 2001, 15 vd.). İslâm'da bu düşünceyi İbn Haldûn'dan önce, transformizmi anımsatan düşünceleriyle Câhız 
(ö.H.255/M.868), inorganik maddelerden organik yapılara dönüșümü/evrimleșmeyi savunan İhvân-1 Safâ (H.334-373/M.945-985), insanı konuşan hayvan, yeryüzünü ise bir mücadele alanı olarak tanımlayan Fârâbî (M.870-950), İbn Miskeveyh (M.920-1020), İbnu'l-Heysem (9651039), Râgıb el-İsfehânî (ö.H.502/M.1008), insanın evrimini melekler âlemine dek sürdüren Mevlânâ Celâledin-i Rûmî (1207-1273) ve Zekeriyâ b. Muhammed el-Kazvinî (M.1203-1283) gibi düşünürler savunmuştur. ${ }^{2}$

Biyolojik evrim düşüncesi alanında ilk adımı Nazzâm atmış olsa da, bilim tarihinde bu konuyu orijinal, bütünlüklü ve ilk olarak 9. yüzyıl düşünürü Câhız (776-869) ortaya koymuştur. Ünlü eseri Kitâbu'l-Hayavân, Doğulu ve Batılı araștırmacılar üzerinde önemli bir etkiye sahiptir. Eserinde, hayvanları lineer bir seri halinde, en basitten en karmaşığa dek bir sınıflamaya tâbi tutmuş, benzer olanları bir grup içerisine alarak işaretlemiş ve bu grupları alt gruplara bölerek türlerde nihai birimlere ulaşmayı hedeflemiştir. Hayvanların yaşamında çevresel faktörlerin etkisini keşfeden Câhız, farklı faktörler altında hayvan türlerinin dönüşümünü gözlemiştir. Aynı şekilde varlık mücadelesinin amacı ve mekanizmin değeri üzerine açılamalar kaydetmiştir. Ona göre evrimin yapısı, üç temel süreç üzerine kuruludur: Yaşam mücadelesi, türlerin birbirine dönüşümü ve çevresel faktörler. Bu üç mekanizmin ilki ve ağırlıklı olanı, yaşam mücadelesi, güçlü olan türlerin hayatta kalması ve sonuçta ortaya doğal seleksiyonun çıkmasıdır. Bu mücadele sadece farklı türlerin üyeleri arasında değil, aynı türün üyeleri arasında da gerçekleşir. Yiyecek, içecek, sığınak ve iklim gibi biyolojik ve psikolojik faktörlerin etkisiyle türler zorlu bir yaşam mücadelesi verirler, değişen çevre ile birlikte türlerin karakter yapıları da değiş̧ime uğrar ve bu değişiklikler üreme yoluyla gelecek nesillere aktarılır. Faslı ve Nabatlı insanların, toz ve toprak gibi çevresel etkilerle bazı maymun türlerine benzediğini işaret eden Câhız, bu etkilerin artmasına bağl1 olarak değişimin ve maymuna benzeme oranının da artacağını vurgular. Türlerin değişkenliği ve birbirine dönüşümü, ona göre çevresel faktörlerin etkisi altında tesadüfen gerçekleşmektedir. Orijinal formlar, tedricen gelişerek yeni formları meydana getirirler. Türlerin mutasyonunda Tanrısal kuvvetler etkin güçlerin ilkidir, diğer faktörler bundan sonra gelir. Bu yaklaşımıyla Câhız, hem çevreye ve değişen koşullara uyum sağlamanın hayatta kalmayla doğrudan bağlantısını, hem de kullanılan ve kullanılmayan organlar konusunu açıklığa kavuşturmaktadır. Bu konudaki düşünceleri, Darwin'in doğal seleksiyon kuramıyla da büyük oranda benzerdir. Câhız'ın düşünceleri İhvân-1 Safâ, İbn Miskeveyh ve İbn Tufeyl gibi Müslüman düşünürleri doğrudan etkilemiştir. İbn Haldûn'un evrim düşüncesi, bunun geliştirilmiş bir formu sayılabilir. Darwin ve Lamark'ın içkin ve materyalist evrim yaklaşımından farkı ise Câhız'ın teolojik ve aşkın bir tavrı benimsiyor olmasındadır. (Bayrakdar, 2012, 120 vd.)

İhvân-1 Safâ' da varlıklar madenlerden başlayarak bitkilere, hayvanlara ve insanlara doğru sürekli yükselen bir çizgide bulunurlar. Aralarında bir irtibat vardır ve her varlığın en yüksek veya son basamağı, kendisinden sonra gelen varlığın en alt veya ilk basamağı ile bağlantılıdır. Böylece organik olmayan madenler toprağın, toprak bitkilerin, bitkiler hayvanların, hayvanlar insanların ve insanlar meleklerin oluşmasına katkıda bulunur. Madenlerle bitkiler arasında mantarlar, bitkilerle hayvanlar arasında asma ve hurma ağacı, hayvanlarla insanlar arasında maymun türü vardır. İnsanların en yüksek türleri, hayatı ilim ve bilgide bulan, gönül gözü açık basiret sahipleri olarak melekler âlemini müşahede ederler (İhvân-1 Safâ Risâleleri, C.3, 181-184).

İbn Miskeveyh (ö.1030), el-Fevzu'l-Asgar' da varlık ufukları arasında benzerlik, bitişiklik ve ayrıklık olduğunu ileri sürerek, varlık türleri dizgesini inci kolye benzetir. Ona göre her türün sonu, kendisinden sonra gelenin ilkini oluşturur. Tohumsuz bitkilerdeki canlılık etkisi gelişerek

\footnotetext{
${ }^{2}$ M. Hamidullah ve M. Bayrakdar hem evrim düşüncesini çeşitli biçimlerde içeren Nüveyrî'nin Kitâbu'l-Hayavân'1, İhvân-ı Safâ Risâleleri ve İbn Tufeyl'in Hayy b. Yekzân'1 gibi eserlerin 19.Yüzyılda Batı üniversitelerinde okutulduğunu, hem de Darwin'in Cambridge'de ilâhiyât okurken Samuel Lee'nin (1783-1852) Arapça sınıfına devam ettiğini tespit etmektedir. (Fr. Dieterici'den akt. Bayrakdar, 2012, 124; M. Hamidullah’tan akt. Yakıt, 1984,101-122). Bayrakdar ve Hamidullah'ın, bu eserleri Darwin'in evrim düşüncesine kaynak olarak görmek iddiası bulunmuyor fakat verilen bilgilerin yalnızca tarihsel birer tespit olmaktan öte olduklarını ve Batı düşüncesinde evrimin kökenleri üzerine yeni ve daha derinlikli araştırmalara gereksinim olduğunu gösterdiğini de kaydedelim.
} 
her bitki türünde ilerler, yükselir ve ağaç türlerine evrilir. Dağlarda kendiliğinden yetişen ve bakıma muhtaç olmayan ağaçlardan, zeytin ve meyve türleri benzeri değerli ağaçlara çıkılır. Bitkilerin son sınırı asma ve hurmadır. Yaratıcının yaygın hikmetinin etkisi artınca bitkiden hayvan türlerine geçilir. Hurmanın tozaklanması/telkîh, hayvanların çiftleşmesine benzer. Hurmanın özü, hayvanın beyni gibidir. Hayvan türlerinin en az gelişmiş olanları istiridye ve salyangozdur. Bunları bitkiden ayıran temel özellik, dokunma duyusudur. Hikmetin etkisinin artmasıyla hareket kabiliyeti de artar. Hayvanlar âleminin en gelişmiş üyesi olan at ve atmaca gibi türler, insanların en az gelişmiş üyesine bitişiktir. Maymun türleri ise diğer hayvan türlerinden uzak özellikleriyle insanlar âlemine daha yakın kabul edilir. Düşünme gücü gelişmemiş insan, maymunla yakın özelliklere sahiptir. Bundan sonra akıl yürüten, konuşan ve ayırt eden varlık olarak insan gelir. İnsanların hayvanla olan farkını belirleyen, yaşadıkları iklim kuşaklarıdır. Kuzey ve Güneyde yaşayan Türk ve zenci kavimleri hayvana yakınken, üç, dört ve beşinci iklim kuşaklarında yaşayan insan toplulukları, düşünce gücü ve hikmeti ortaya koymaları bakımından da üst düzeydedirler. Bu uç iklim kuşaklarında yaşayanlar, uygun iklim koşullarına geldiklerinde evrimleşirler. Bu yükselmenin son noktasında insan, meleklerle iletişime geçme becerisi kazanır. Bu, Kur 'ân'da Rûh, Rûhu'l-Kuds veya Cibril olarak anılan vahiy meleği ile insanın ilişkisini de açılar. Böylece vahiy ya sürekli düşünme etkinliği gerçekleştiren ve melekî seviyeye yükselen kimselerin ulaştığı bir hakikat olur ya da bu seviyeye yükselmeye gerek olmaksızın yukarıdan aşağıya doğru kendisine iner ve ilahî bilgi, kişinin önünde açıkça serili hale gelir. Aşağıdan yukarıya yükselen kişi felsefe yapan/filozof, ilahî bilginin yukarıdan aşağıya akarak kendisine ulaştığı kişi peygamberdir. İhvân-1 Safâ'da arılar, atlar, maymunlar gibi canlılar insanla benzerlik arz eder ve maymun özelinde insan hayvanlaştırılırken, İbn Miskeveyh'te maymun, insanlar âlemine dâhil edilir. (İbn Miskeveyh, 2014, 254 vd.) İbn Haldûn'un varlık ufukları kavramı İbn Miskeveyh'ten mülhem görünmektedir. Ayrıca teorisinde yer alan asma ve hurma türleri, insanın maymuna benzemesi ve evrene içkin bir tedricîliğin bulunması düşünceleri de, İbn Haldûn ve Râgıb el-İsfehânî ile benzerlik gösterir (Yakıt, 1984, 106).

İbn Tufeyl (ö.1185), Hayy b. Yakzân kurgusunda, insanın ilk olarak ya bir anne-babadan dünyaya geldiğini, ya da yaşamaya en elverişli sıcaklığa sahip dördüncü iklim kuşağında bir adanın ortasında, yıllar içinde mayalanmış, sıcakla soğuğun, yaşla kurunun tam bir uyum ve dengesine ulaşmış bir çamurdan meydana geldiğini anlatır. Ona göre bu mayalanmış çamur, büyük bir kütleye, mutedil bir mizaca ve uygun bir ortama sahiptir. Zamanla kabarmaya başlayan çamur, kabarcıklar çıkarır ve en uygun bir hava veya benzeri saydam bir cisimle dolu olan kabarcığın içinde yer alan iki yapışkanımsı bölüme, Allâh'ın emri ile ruh tutunur. Ardından meydana gelen yeni kabarcıklar, insanın organlarını oluşturur. Ona göre bu süreç, insanın anne karnındaki gelişim süreciyle benzerdir. (İbn Tufeyl, 2003, 24 vd.) İbn Tufeyl' in insanın kökenine ilişkin düşünceleri, İbnu'n-Nefis' in düşünceleriyle paraleldir. Aralarındaki farklardan biri, İbnu'n-Nefis, ruhun, çamurun mayalanması sonucunda ortaya çıkan buhar gibi havamsı latif bir cisimden oluşmuştur. Dolayısıyla o da Galeanos gibi ruhun cismanî bir yapıda olduğunu iddia etmektedir. İbn Tufeyl'e göre ilk insan çamurun ortasından bebek olarak dünyaya geldiğinden bir hayvanın/ceylan bakımına muhtaçtır. İbnu'n-Nefis ise ilk insanın/Kâmil on-on iki yaşlarında bir genç olarak bir mağaranın ağzında dünyaya geldiğini, dolayısıyla herhangi bir hayvanın bakımına ihtiyaç duymadığını belirtir. Doğada içkin ilahî hikmetleri akılarıyla kavrayan bu iki kahramandan Hayy, toplumsal yaşamdan uzaklaşıp doğduğu adaya sığınırken, Kâmil, toplumsal yaşama uyum sağlar ve doğduğu adaya geri dönmez. (Bayrakdar, 2001, 78 ve 81 vd.) İbn Tufeyl'in orantılı biçimde karışmış ve mükemmel biçimde dengelenmiş bir inorganik maddeden organik varlığın ortaya çıkışını içeren bu düşünceleri, hem yaşamın bir anda ortaya çıkması düşüncesinin reddidir hem de modern teorilerle son derece uyumludur. (Hawi, 2003, 268).

Hz. Mevlânâ cansızlardan kalkıp insana dek uzanan, oradan insanın melekler âlemine geçişini mümkün kılan bir silsileden söz eder ve Mesnevî’nin farklı yerlerinde yalnızca insana dek sürdürdügü silsilevî evrim yolunu, yalnızca bir yerde melekût âlemine dek uzatır (Mevlânâ, C.4, 636, b.3637 vd). Zekeriyâ b. Muhammed el-Kazvinî ise insanın hayvanlar âlemiyle melekler âlemi arasında yer almasından söz ettiği halde maymunlardan söz etmez (Yakıt, 1984, 106). 
Böylelikle İbn Haldûn'un evrime ilişkin düşüncelerinin büyük oranda İhvân-1 Safâ ve İbn Miskeveyh'ten kaynaklandığı söylenebilir.

İbn Haldûn'un varlı̆̆ın ve insanın evrimine ilişkin düşüncelerini daha iyi anlayabilmek ve bilim tarihindeki yerini doğru tespit edebilmek için, öncülleri olan İslâm düşünür ve bilim adamlarıyla birlikte Ch. Darwin'in de evrime ilişkin düşüncelerini kısaca hatırlatmakta fayda var.

Darwin, insanın en eski dönemlerden itibaren yabanî hayvanları çiftleştirmek ve evcilleştirmek suretiyle türlerin fiziksel ve fizyolojik olarak değişime uğradığını ileri sürmüş, buna ilişkin gözlemlerini Galapagos Adaları'nda tamamlamıştır. Gözlemlerinden hareketle doğal seçilim, çevreye uyum, kalıtım ve cinsel ayıklama gibi etkenler altında tüm canlı türlerinin az sayıdaki ilkel canlı türlerinden türediğini ve insanın köken itibariyle daha az gelişmiş maymunumsu ilkel bir canlıdan türeyerek ortaya çıktığını ileri sürmüştür. Darwinizm adı verilen evrim teorisinin özü budur. 20. yüzyılda ise Yeni Darwinciler tarafından teori, canlılarla birlikte sosyal hayatın oluşumunun, tarihin ve dinlerin kökeninin de açıklandığı genel bir nazariyeye dönüştürülmüştür. Darwin'in evrim teorisinin en önemli parçası doğal seçilim/selection kuramıdır. Acımasız bir hayatta kalma mücadelesinin ve sert bir rekabetin sonunda, türün kuvvetli olan üyesi hayatta kalır ve hayatta kalmasını sağlayan seçkin niteliklerini kalıtımsal olarak gelecek nesillere aktarır. Buna göre 1) organizmalar değişir ve değişimler kısmen de olsa kalıtımla yavrulara aktarılır, 2) organizmalar, hayatta kalabilecek olanlardan daha fazla sayıda yavrular ve 3) çevre koşullarına ortalama olarak en uygun biçimde değişiklik gösteren yavrular hayatta kalır ve ürer. Böylece, yararlı değişiklikler doğal seçilim yoluyla topluluklarda birikir. Burada önemli bir husus olarak Darwin'in doğal seçilimi yaratıcı bir kuvvet olarak tasarladığı ve böylece değişikliklerin rastgele olması ve tercihli bir uyuma dönük olmaması gerektiği vurgulanmalıdır (Darwin, 2012, 80 vd.; Gould, 2002, 1). Bu rastgeleliğe karşın dünya hâlâ bir ahenk ve düzen sergiliyorsa, bu sadece bireylerin kendi çıkarlarını gözetmelerinin rastlantısal bir sonucudur. Hayatta kalma mücadelesi, bireylerin bencil duygularını pekiştiren bir süreçtir. Buna karşın bencilce eğilimlerle kendi çıkarını gözeten bireyin davranışlarının, tersine sosyal bir empati duygusunu doğurduğu da ileri sürülmüştür. Tüm canlılar ortak bir atadan küçük değişikliklerle evrimleşerek meydana gelirler. Canlıların ortak bir atadan geldiği düşüncesine bağlı olarak her canlı kendisinden önce gelen canlı türüyle bedensel, zihinsel hatta ahlâkî ortak özellikler taşır (Torun, 2014, 176). Doğal seleksiyonda yine rastlantısal kabul edilen ahlak da insandan önceki türlerde içgüdüsel olarak bulunur ve insanın ahlâkı köpek, inek ve at gibi hayvanlardan aldığı ileri sürülür (Torun, 2014, 177-187). Buna karşın Darwin, en gelişmiş hayvan türlerinin bile davranışlarının sebebi üzerine düşünme yeteneğinin gelişmediğini vurgular (Darwin, 1994, 45 vd.; Torun, 2014, 182). Çünkü ahlâk evrim geçirmiş insana özgüdür ve ahlâkın kaynağı vicdandır (Darwin, 2009, 84; Torun, 2014, 185).

İnsanla maymun arasında genetik ve yapısal bir ilişki bulunur ve insan fosil araştırmalarında maymun, insansı maymun ve insan fosilleri, bu genetik bağın birbirinden farklı, yakın ve bitişik duraklarını teşkil eder. Maymun türleri ile insanın evrimsel aşamaları arasında sık1 ve doğrudan bir bağ kurulduğunda, insanın doğal seçilim sonucunda ve kendine has evrimsel güçleriyle varlığa geldiği ve Tanrısal herhangi bir yaratım kuvvetinin bu varoluş sürecinde etkin olmadığı kanıtlanmış olacaktır. Bu anlamda 19. yüzyıl düşünürlerinden Thomas Henry Huxley (1825-1895), insan/homo sapiens beyninde bulunan hipocampus minörün aynı zamanda şempanzeler dâhil tüm insansı maymunlarda, Prosimii alt takım üyelerinde ve tüm primatlarda ortak olduğunu göstermiş ve insanın maymun türlerinin bir devamı/türevi olduğunu ileri sürmüştür. Kafatasımızın anatomik yapısı da bu kanıta eklenebilir. Onun dönemsel rakibi Richard Owen (1804-1892) ve takipçileriyse, bu kanıta kökten bir itirazla insanın doğadaki biricikliğini tesis etmeye çalışmışlardır. Bu iki düşünür arasındaki tartışma, Batı bilim dünyasında günümüzde de sürmekte olan tartışmanın bir özeti gibidir. Huxley'nin şempanzeler üzerine kurulu savunması, 70'li yıllarda yapılan deneylerle derinleştirilmiş, insandan anatomik olarak fazlaca farklı olmayan bu canlıların zihinsel olarak da çok geri olmadıkları, örneğin üç aylık bir eğitimle sağır-dilsiz iletişimini kavradıkları ve birkaç kelimelik hazneye ulaştıkları görülmüştür. Dolayısıyla insanı 
şempanzeden derece farkıyla ayıran evrimciler için insan da hayvandır. Tersine, şempanzelerin birkaç kelime öğrenmelerine rağmen doğal ortamlarında ve kendi aralarında daha zengin bir iletişim becerisine sahip olduğuna dair kanıt olmadığını ve bu iki türün görünüşlerinin ötesinde daha derin farklara sahip olduğunu savunanlar içinse insan, şempanze ile kardeş değildir. Evrim taraftarlarına göre, ortak gen kolundan gelen bu iki tür, gelişim olaylarının zamanlamasını kontrol eden genlerin oluşturduğu düzenleyici bir sistemle, birbirinden ayrılmış ve kendilerine has yapılara kavuşmuştur (Gould, 2002, 54 vd). Ancak, gelişme/development veya değişmeyle/changement ilgili olayların zamanlamalarını kontrol eden genlerin bulunması, değişmenin öncesinde ona amaçlı bir yön veren belirleyici bir üst kuvvetin varlığına ve evrimin rastlantısal olmadığına işaret eder. Bu, Darwin'in baştan reddettiği bir düşüncedir.

İbn Haldûn'un Darwin'in habercisi sayılması, üst âleme geçebilme istidadı kavramının, Batı dillerine evrim olarak tercüme edilmesinde saklıdır (Câbirî, 2018, 78) ancak tercümelerde Arapça evrim/tatavvur kavramının, ilerleme veya tekâmül/irtika kavramından farklı bir anlama sahip olduğu göz ardı edilmiştir (Husrî, 2001, 164vd). Bu bağlamda İbn Haldûn ile Darwin arasında kurulmaya çalışılan kavramsal bağ zayıflamaktadır.

\section{1. İbn Haldûn'da İnsanın Evrimi}

İbn Haldûn Mukaddime'de evrim düşüncesini İnsanın Evrimi, Kimya ve Tasavvuf olarak üç farklı bölümde ele alır. Ayrıca Gaybın Bilinmesi, Cefr, Vahiy Alma, Rüya, Kehanet ve Arraflıkla ilgili bölümlerde de bu konuya dolaylı olarak değinmiştir. İbn Haldûn varlıklar âlemini birbiriyle bitişik, yakın ilişki içerisinde ve yekdiğerine bağlı şeyler, olaylar, sebepler ve sonuçlarla örülü olarak tasarlar. Bu durum, ortaya mükemmel ve hayret verici bir düzen çıkarmaktadır. Evrendeki bu mükemmelliği kavramak için maddî ve maddî olmayan unsurlar ayrı ayrı ele alınmıştır. Ona göre maddî ve maddî olmayan unsurlar evrende bir düzen/ahenk ile birlikte yer alırlar. Maddî varlıkları meydana getiren dört unsur, topraktan suya, sonra havaya ve en sonda da ateşe dönüşmek üzere değişmekte/başkalaşmaktadır. Varlıklar âleminde yukarı çıkıldıkça kesafet azalır letafet artar, toprak kesif bitki latiftir. Buna karşın bitki kesif hayvan latiftir. İnsan hayvana göre, melek insana göre, felekler âlemi maddî âleme göre daha latif ve incedir. Bu dört unsurun birbirine dönüşmekte olduğu, katı varlıklardan çıkan suyun incelerek buhara ve havaya dönüştüğü, tersine buharın da donup katılaştığ gündelik bilgidir. Oluş-yok oluş âleminde, alt tabakadaki varlıkların en yüksek örneğinin, üst tabakadaki varlıkların en aşağı örneğine bağlı ve yakın olması da böyledir. Felekler âleminde yer alan varlıkların mükemmelliği son derecededir, göksel hareketleri dışında duyusal veya maddî değillerdir. Aşağıdan yukarıya doğru yükselerek ilerleyen bu tekemmül süreci, bu anlamda daha yukarıda ve daha mükemmel varlıklar hakkında bilgi edinmemize de imkân vermektedir. İbn Haldûn'a göre oluş-bozuluş/kevn $\hat{u}$ fesâd döngüsü üzerine kurulu varlıklar âleminde insanlar, hayvanlar âlemi dışında ve ona bitişik farklı bir varlık evreni oluşturmaz, hayvanlar âlemine dâhildir ve özel anlamda gelişmiş bir tür maymundur. Ancak İbn Haldûn araştırmacılarından bir kısmı Mukaddime metninde maymun ifadesinin yer almadığını iddia etmişlerdir. Mukaddime'nin Beyrût Nüshâsı'nda kuvvetler âlemi/a 'lemi'l-kuvve diye kaydedilen bu kavram, Vâfî, Pîrîzâde ve Rosenthal gibi farklı bazı nüshalarda maymunlar âlemi/a 'lemi'l-kırede olarak kayıtlıdır. Uludağ gibi araştırmacılarsa kavramın maymunlar âlemi şeklinde okunması gerektiği görüşündedirler. Gerçekten de ifadenin öncesi ve sonrası dikkate alındığında, bu ikinci okumanın doğru olduğu anlaşılmaktadır (İbn Haldûn, 2001, 121; İbn Haldûn, 1988, C.1, 283; çevirenin dipnotu, aynı yer).

İbn Haldûn varlıklar evrenini hareket prensibi üzerinden bir sinıflamaya tâbi tutar, hiyerarşinin ilk basamağında yer alan madenlerin en yüksek ve son ufku, bitkiler âleminin ilk ve en alt ufku olan tohumlar ve çayır otlarına bitişiktir. Tohumlar hareket etmemek bakımından cansız varlıklardan ayrılmazken, uygun nem ve 1şık koşulları sağlandığında, potansiyel olarak özlerinde barındırdıkları canlılık özelliğini açığa çıkarırlar. Çayır otları ise bitkiler âleminin en değersiz üyeleridir. Bitkiler âleminin son ve en yüksek ufku hurma ve asmadır ve hayvanlar âleminin en ilk ve en alt ufku olan salyangoz ve midyeye bitişiktir. Dişi hurma ağaçlarının polenlenmesinde bir rastgelelik yoktur, bir nevi duygusal bağ kurdukları tek bir erkek ağaçtan 
polen kabul ederler. ${ }^{3}$ Bitkilerin hareket ettiği güçlükle sezilir ve toprağa bağlıdırlar. Midyeler ve salyangozlar da, esasen öyle olmadıkları halde adeta toprağa bağlı bulunurlar ve hareketleri güçlükle sezilir. Hayvanlar âleminin son ve en üst ufkunda, düşünme ve idrak etme varlığı olan insan yer alır. Varlık hiyerarşisinde aşağıda çokluk, yoğunluk ve kabalık, yukarıya çıkıldıkça letafet, incelik ve azlık hâkimdir (İbn Haldûn, 2001, 121; İbn Haldûn, 1988, C.1, 284). İnsana en yakın tür, bedensel hareketleri ve fonksiyonel kuvvetleri son derecede geliştiği halde idrak kuvveti gelişmemiş olan maymundur. Böylece insanın maymundan geldiği ve bir tür maymun olduğu söylenebilir. Bu açıdan bakıldığında başka bazı hayvanların da fizik ve duygu bakımından insana benzediği fakat düşünme, refleksiyon/reviyye, düşünce geliştirme ve idrak bakımlarından insandan uzak olduğu görülür. İnsan, hayvanlar zümresinden düşünsel ve fikrî tabiatı ile ayrılır, temâyüz eder (İbn Haldûn, 2001, 736; İbn Haldûn, 1988, C.2, 981).

İnsanın felekler âlemine yükselerek buraya dâhil olması ve meleklerle ittisali de potansiyel bir imkân olarak bu bağlamda ele alınır. İnsan türünün, duyusal bakımdan en yüksek örnekleri olan peygamberler ve veliler, fiziken değil fiilen ve ruhen bu imkâna sahiptirler. Dolayısıyla insan, doğası bakımından başkalaşıp bedensel bir değişim/dönüşümle fizik varlığından kurtularak melekleşmez, bir takım özel yetenekleriyle yalnızca ruhî melekelerini ve istidadını son derecede geliştirip ruhsal olarak yücelerek/incelerek bu âlemle ittisal eder. Darwin'de fiziksel ve akılsal düzeyde ele alınan insanın evrimi, İbn Haldûn'da yalnızca ruhsal düzeydedir çünkü insanın letafeti ancak bu seviyede gerçekleşebilir. İnsanın fizikî anlamda letafeti mümkün değildir. Bu, garip/'acib, yakın/karîb ve doğal/tabî̂ bir süreçtir. Darwin'den farklı olarak evrim sürecine deney dışı dünyayı da dâhil eden İbn Haldûn için temel olarak üç grup ruhtan söz edilebilir. Bunların birincisi insanların çoğunun sahip olduğu en aşağı, kaba ve yoğun/kesif ruhtur. Beș duyu ile kavranan duyusal dünyayla sınırlı, ilahî âlemden habersiz veya onunla ilgili olmayan bir hayata yönelmiş kimselerin ruhları böyledir. İkinci grup ruh, daha ince/lâtîf ve azdır. Esas itibariyle velilere has olan bu ruh, düşünsel faaliyet ve harekete yönelmiştir, ruhanî akıl ve bedensel organlara muhtaç olmaksızın düşünme ve idrak yeteneğine sahiptir. Sıradan insanın çalışarak/kesbî ulaşmasının mümkün olmadığı bu seviyede Allâh'ın lütfu ile ledünnî bilgi/marifet elde edilir. Melekler âleminin en alt seviyesine ittisale imkân veren bu istidat velilere özgüdür. Nebilere özgü çok az sayıdaki üçüncü grup ruh ise diğerlerine göre en yüksek letafet ve inceliğe sahiptir. Melekler âlemine geçmek için sahip oldukları istidat, onları göz açıp kapayıncaya dek geçecek bir kısa zaman içinde beşeriyetten sıyrılıp bilfiil melek cinsinden olmaya ve melekler âleminin en üst örnekleri seviyesine yükselmeye götürür. Sadece nebilerin sahip olduğu bu kuvveti, Fârâbî, İbn Sînâ ve İbn Rüşd gibi İslâm filozofları el-kuvvetu'lkudsiyye olarak adlandırmışlardır (İbn Haldûn, 1988, C.1, 288, dipnot 29).

İnsanlar âleminin son ufkuna komşu sirf irade ve saf akıl varlıkları olan melekler âleminin varlığından, insanda bulunan idrak ve irade kuvvetleri gibi eserleri vasıtasıyla haberdar olunur. Dolayısıyla beşeriyetten melekîliğe yükselme istidâdı kendisini sadece akılsal perdede gösterir ve insanlık âleminden çıkıp yükselerek melekler âlemine geçmek, insan için ancak akılla mümkündür. İnsanın saf irade ve akıl âlemine yükselmesi, bedensel veya maddî kuvvetlerin tümünden kurtulmasını ve yalnızca akıl ve irade kuvvetlerini kullanmasını gerektirir. O halde bu yükselme, tam bir evrimleşme değil, sadece yetenekleri bakımından seçkinleşmeden ibarettir. Vahiy veya meleklerin hitabı böyle gerçekleşir ve peygamberlere hastır. Vahiy alma esnasında yaşadıkları haller ve açığa çıkan değişimler de hepsinde ortaktır. Bu yaklaşım, filozofların ifadelerini ve özelde On akll Teorisi'ni anımsatsa da İbn Haldûn bundan farklı olarak aracı bir faal aklın varlığını ve akılsal yükselmenin sonucunda Allâh ile tevhidi reddeder. Bu noktada felsefeyi reddi ile tasavvufa yönelik eleştirilerinin paralelliği hatırlanmalıdır (İbn Haldûn, 1988, C.2, 872; Kâtip Çelebi, 2007, C.1, 679; C.2, 566).

\footnotetext{
${ }^{3}$ Bilindiği üzere hurma ağacı da asma gibi dişi ve erkek olarak iki cinstir. Meyveyi dişi verir ancak meyve verebilmesi için erkek olandan alınan polenlerle döllenmesi/telkîh gerekir. Hurmanın dişisinin tıpkı insanlara benzer şekilde karşısında duran erkekten döl aldığı, başka yerden getirilen polenleri kabul etmediğinden hareketle Arap geleneklerinde hurmanın âşık olduğu düşüncesi hâkimdir (Kütüb-i Sitte, 2014, C.16, 418).
} 
İbn Haldûn'da varlıkların evrimi, zorunlu değil potansiyel bir yapı taşır ve varlıkların doğalarından daha çok istidatlarında, yeteneklerinde ve içlerinde barındırdıkları imkâna bağlı olarak gelişir. İbn Haldûn'da türlerin seçilimi kendilerine hastır. Örneğin köpek ve maymun gibi farklı türler arasında birbirlerine doğru geçişler söz konusu değildir. Bu durum Darwin'de de böyledir. İnsana en yakın ve istidatları bakımından tam ve mükemmel bir hayvan türü olan maymundan insana geçiş özel ve istisnaî bir durumdur. İbn Haldûn'da bir fark olarak maymun türleri, başkalaşarak düşünce üreten, refleksiyon yapan ve idrake sahip insana dönüşemezler, ancak yetenek ve maharetlerini son derecede geliştirerek, insan türünün en aşağı noktasında yer alan, fizik yapısı henüz tamamlanmamış, el becerileri gelişmiş fakat düşüncesi ve konuşma becerisi yeterince gelişmemiş bir örneğe evrilebilirler. Ayrıca her varlık için geçerli olmayan bu durum potansiyel bir durumdur, bilfiil ve zorunlu değildir. Maddî ve gayrî maddî varlıkların tümel/küllî/yekpare bir yapı içerisinde evrimleşmesi süreci, işte bu yönleriyle acayip, hayrete şayan ve anlaşılması güçtür. Dört unsur ile melekler arasındaki ayrımın ortadan kalktığ 1 bu teori, tüm varlığı tek bir kurgunun kendilerine has parçalarına dönüştürür ve temelde İbn Haldûn'un evreni ve yaratmayı anlama yöntemidir. Evrimi yaratıcı bir kuvvet olarak tasarlayan Darwin'de bu türden bir kesintisizlik ve geniş düzeyde kapsayıc1lık bulunmaz.

İbn Haldûn'a göre insan varlığı ruh ve beden olarak iki parçadan müteşekkildir. Ruhun bilfiil yönü akıl veya idraktir/taakkul. Bilfiil olmayan yönü ise bedensel kuvvetlerle/vasitalarla kuvveden fiile geçirilir. Çocukların zayıflığı veya tamamlanmamışlığı böyledir. Tümelleri soyutlanma süreci ve akletme kuvveti tamamlandıkça insan olgunlaşır ve âlemi iki yönüyle dolaylı/cismanî ve dolaysız/ruhanî olarak kavrar. Ruhun önünde engel ve dolayım teşkil eden cismanî bedenin aradan çıkarılmasıyla perde açılır ve rüya, kehanet/fal ve tasavvufî riyazetle ruhanî kavrayış ortaya çıkar. Böylece doğrudan deneylenen ruhanî varlıklar/gayb ya oldukları gibi anlaşılır ya da daha çok hayal kuvvetine/muhayyile sevk edilerek çeşitli kalıplar halinde kavramlaştırılırlar (İbn Haldûn, 1988, C.1, 300).

Peygamberlerin melekler âlemine ittisal etme yeteneği ve bu yeteneği iradî olarak kullanabilme maharetleri, vahiy almanın farklı türden bir açıklamasıdır. İlahî bilgileri/vahiy, rabbânî marifetleri ve dînî ilimleri almak üzere, beşerî ve ruhanî varlığından sıyrılan peygamber, kısa süreliğine meleklik vasfı kazanır, ardından yeniden beşerî özelliklerine geri dönerek bu bilgileri insanlara tebliğ eder. Ancak din dilinde, verilen veya peygamberin edilgin bulunduğu bir süreç olarak bilinen vahiy, İbn Haldûn'un evrim anlayışında peygamberin etkin ve iradî fiillerinin sonucunda alınmaktadır. Vahiy, aynı zamanda bununla görevli bir melek tarafından yine seçilmiş bir insana getirilen Tanrı buyruğu olduğu halde, İbn Haldûn bu özel hadiseyi bir anlamda otomatikleştirerek teknik bir meseleye dönüştürmektedir. Buna göre insanlar âleminin son ufkunda yer alan her insan, buna komşu saf akılsal melekler âlemine geçebilir. Bu imkân tüm insanlara açıktır ancak istidadı yalnız peygamberlere hastır. Bu açıdan İbn Haldûn'un evrim sürecini sürdürmek ve sistemin bütünlügünü sağlamak amacıyla yaptığı bu açıklama, bilindik vahiy alma hadisesinden farklı olmakla eleştiriye açık olsa da, varlık türleri arasında sınırlı organik, biyolojik, küllî ve kapsayıcı bir bütünlük, süreklilik ve bağ kurulmuş olur. Darwin'in evrim kuramı bu türden bir bütünlük arayışından uzaktır.

İbn Haldûn fizikî veya biyolojik bir yapıda düşünmediği insanın evrimini akılsal veya ruhsal bir kemal seviyesi olarak tasarlamakta ve düşüncesini eski insanlar, toplumlar ve umranın doğasından hareketle delillendirmektedir. Bazı ravîler, eski insanların boy, kilo ve kuvvet bakımlarından sonrakilere nazaran daha büyük olduklarını ileri sürerler çünkü onlardan kalan eserler daha büyük ve heybetlidir. Örneğin Mısır piramitleri akıl almaz büyüklüktedir. Bu anlamda eski kaynaklarda bu türden yapıların, fizîken daha büyük ve güçlü insanlar tarafından yapıldığına ilişkin rivayetler mevcuttur. İbn Haldûn'a göre ise eski insanlarla kendi dönemindekiler arasında yapısal bir fark bulunmaz. Söz konusu yapıların büyüklüğü hayret verici olsa da; evlerin, meskenlerin, kapıların, pencerelerin ve genel mânâda yaşam alanlarının daha büyük insanlar için yapıldığını gösteren bir delil yoktur. Diğer bir ifadeyle binaların kendileri büyüktür ancak kapı ve pencere gibi yapısal unsurları normal boyutlardadır. Bu anlamda bu 
binaların teknik icatlarla imar edildiği düşüncesi daha makuldür. Dolayısıyla büyük ve dayanıklı binaların varlığı, eski insanların bedensel olarak daha büyük olduklarının değil, işlerinde daha iyi olduklarının, bu binaları yapmak için gerekli asabiyyelerinin daha kuvvetli, toplumsal yardımlaşmalarının daha sağlam, dayanışma ve mühendislik bilgisinde ileri ve işlerinde daha mâhir olduğunun kanıtıdır. Benzer şekilde bu binaların yapımına ilişkin devlet harcamalarının kayıtlarını abartılı bulanlar olabilir ancak o türden güçlü ve büyük devletlerde yaşamış olanlar için bu şaşırtıcı olmayacaktır. (İbn Haldûn, 2001, 429; İbn Haldûn, 1988, C.2, 632). O halde söz konusu eserlerin inşası ve imarı imkân dâhilindedir. İmkânı mantıkî/aklî ve fizikî/doğal olarak iki kısımda ele almak mümkündür. Felsefede sıkça kullanılan bir örnekle kanatlı bir at düşünmek aklen mümkün fakat bunun fiziken varlığı imkânsızdır. Fiziken veya doğal olarak imkânsız olan bir şeyi aklen tasavvur etmeye ise bir engel yoktur. Tarihi/toplumsal bir mesele, günün toplumsal ilkeleri veya dinamikleri bağlamında değerlendirildiğinde ortaya çıkan hüküm geçerli olacaktır. Suyun suya benzediği gibi insan insana, toplum da topluma benzer. Bu binaların bugün inşa edilmesi aklen ve fizîken mümkünse, o gün de buna imkân var demektir. $\mathrm{Bu}$, umran teorisinin evrensel prensibidir.

\subsection{Kimya veya Evrimin İmkânı}

İbn Haldûn'a göre kimya, ‘hem altın ve gümüş üretmek üzere iksir hazırlama ve bundan medet uman kimselere satarak geçimini temin etme, hem de madenlerle hayvanların ve insanların tüy, kemik, dışkı vb. unsurlarını inceleyip doğalarını anlama ilmidir' (İbn Haldûn, 2001, 695; İbn Haldûn, 1988, C.2, 940). Kimyacılar, belirli kimyasal bir bileşikle/iksir madenleri birbirlerine dönüştürmenin yolunu bulduklarını ve örneğin gümüşü altın, bakırı gümüş yapabildiklerini ileri sürerler. Dönüştürücü iksir veya şerefli taş/hacer-i mükrem, mayanın hamuru kendi özüne döndürmesi gibi, temelde yedi adet madeni -altın, gümüş, bakır, kalay, kurşun, demir ve hâr-1 sînî/hârsînî - doğal bir süreçle altına gümüşe döndürmektedir (İbn Haldûn, 2015, 289; İbn Haldûn, 1988, C.2, 965). Buna göre madenlerin doğasından hareketle ortaya çıkarılan bu dönüştürücü taş önce dövülerek un haline getirilir, içine katılması gereken diğer maddeler katıldıktan sonra sulandırılıp ateşte kaynatılır. Ardından güneşte kurumaya bırakılır. Geriye bazen bir tür toprak, bazen sıvı kalır. Altın veya gümüş formunu kabul etmeye en yakın madenlerden kalay, bakır veya kurşun ateşte kızdırıldıktan sonra bu iksirin bir miktarı ile karıştırılır ve o anda halis altın ortaya çıkar. Bu işlemde iksire ruh veya canlı ruh, madene beden denir.

Varlıkların değişimi/dönüşümü hakkında, Endülüs hukemâsı ve Fârâbî, birbiriyle aynı türden ve aynı öze sahip olan, yalnızca sertlik-yumuşaklık, sarılık-beyazlık-siyahlık gibi ârazları bakımından birbirinden ayrılan bu madenlerin birbirlerine tümüyle dönüştürülebildiğini kabul ederler (Fârâbî, 1951, 65 vd). İbn Sînâ ise, bu madenlerin türlerinin bir ve aynı olmadığını ve bu türden bir değiştirip dönüştürme kuvvetinin ancak Yüce Allâh'a has kılınabileceğini ileri sürer (İbn Sînâ, 1952, 47 vd). Tuğrâi de İbn Sînâ'nın yanıldığını çünkü kimyanın yaptığı şeyin yaratmak değil dönüştürmek olduğunu belirtir. Ona göre "kimyanın işlevi, yaratılmış varlığı, farklı türden ârazlar almaya hazırlamaktan ibarettir. Örneğin kırılan öküz boynuzu yere ekilir, zamanı gelince içi balla doldurulur ve bundan şeker kamışı çıkar, ölen arılarınsa buzağılardan yeniden meydana geldikleri bilinen bir şeydir. Dolayısıyla farklı türden varlıklar arasında geçişler ve dönüşmeler olağandır." İbn Haldûn'a göre, Tuğrâî'nin bu sözleri hakikati yansıtmaktan uzak birer söylencedir. İbn Haldûn içinse kimyada öncelikle, 'bir varlığın başka bir varlığa dönüştürülerek farklı ve daha değerli bir öze kavuşturulması' ilkesi ve bu amacın gerçekleşip gerçekleşmediği akılsal yollardan denetlenmelidir. Ona göre -İbn Bişrûn'dan alıntıyla- kimyanın dönüştürücü kuvvetlerinin ilki boyanın beyaz beze geçmesi ve onu kendi rengine boyamasıdır. Burada boya

\footnotetext{
${ }^{4}$ Hâr-1 Sînî/Hârsînî; ham altın veya ayna imalinde kullanılan bakır gibi, demire benzeyen, dokunduğu yerde kıl bitmeyen veya dokunduğu şeyi hemen öldüren bir maden olarak tanımlanır. Bu maden hakkında, Çin'de bu madenden yapılan aynalara bakanların ağzı eğri veya yüzü çarpıksa düzeldiği vs. türünden efsanevî sözler de rivayet edilir. Bazı yazarlara göre bu çinkodur/tûtiya, eğer demir sülfatla/zâc karıştırılırsa rûh-i tûtiya olur. Eski kaynaklarda her iki şekliyle de geçer. $\mathrm{Bu}$ madenlerin göz hastalıklarına iyi gelmesi ve okların ucuna sürülerek dokunduğu kimseyi öldürmesi, asl1-astarı olmayan bir söylencelerdir (İbn Haldûn, 2015, 289).
} 
özü itibariyle yok olur, bez bâki kalır ve renk değiştirir. İkincisinde ise, toprağın bitkiye geçmesi veya hayvanın bitkiyi hazmetmesi gibi, var olan öz değişip yepyeni ve farklı bir öze dönüşür. Böylece bitkinin içinde toprak, hayvanın içinde bitki gibi, madde/canlı ruh ve cevherleri/ecrâm, tabiî bir süreçle, özlerini tümüyle yitirerek farklı bir öze dönüşürler. Bu iki kuvvet, varlıkların başka varlıklara dönüşebileceğinin bir kanıtıdır. Ancak iksirle maya birbirlerine benzer kabul edilemez çünkü maya, hamuru daha kolay sindirilmesi için kontrollü biçimde bozarken/fesâd, iksir değersiz bir madeni daha değerli bir hale -oluşma, yaratma anlamında- dönüştürür/tekvîn. Bozulma oluşuma, fesâd tekvîne, maya iksire nispet edilemez. Dolayısıyla kimya/simya iddia edildiği gibi doğa ilimlerinden değildir (İbn Haldûn, 2001, 695; İbn Haldûn, 1988, C.2, 940).

Toprağı değiştiren ve bitkiye dönüştüren kuvvet/kimya taşı, madende veya toprakta değil bitkide; bitkiyi değiştirip hayvana dönüştüren kuvvetse bitkide değil hayvanda içkin bulunur. Böylece bitkiler ve hayvanlar, kendileriyle beslendikleri varlıkları kendilerine dönüştürürler. Dönüşen varlıklarda ise kendinden daha latif bir varlığa dönüşmek arzusu ve yönelimi vardır. İbn Haldûn'un evrim düşüncesinin sürekliliği bakımından, bitkilerin ve hayvanların da kendileriyle beslenen ve kendilerinden daha latif bir varlık olan insana dönüşmesi mümkün görülebilir. Fakat ona göre, insan gıda olarak kullandığı bitki ve hayvanları kendi özünde dönüştürdüğü halde, dönüştürücü iksirin etkisinden uzaktır, kimyasal bir bileşik olan iksirin âlemde hayvandan öteye sirayet edeceği başka bir varlık yoktur ve iksirle dönüşüm hayvandan öteye geçmez. Kesif bir varlık olan hayvan daha latif bir varlık olan insana değil, kesif başka varlıklara dönüşür. Çünkü varlık âleminin en latif unsuru olan ruhun hayvana dönüşmesi, aslında yalnızca şeklen benzeşim biçimindedir. Örneğin bitkilerin ruhları, insanlar veya melekler gibi latif değil, kendileri gibi kesif olduğundan hareket edemez. Ateşe tutulan varlığın eriyip buharlaşması, bir anlamda eski ruhanî yapısına geri dönmesi ve bedensel olduğu halde üzerinde ruhsal bir hal barındırması demektir. Hareket eden ruh/hayvan, sakin ruha/bitki göre daha latiftir. Soluk almak ve gidayı kabul etmek bakımlarından hayvan bedeni, kimyevî muameleye daha açık ve daha uygundur. Dolayısıyla madenler, bitkiler ve hayvanlar üzerinde dönüştürme etkisine sahip kimyevî madde, esas itibariyle insana yükselecek denli kuvvetli değildir. Bu iksir; çok sayıda maden veya varlıktan onunla aynı öze sahip yalnızca bakır, kalay veya kurşun gibi madenleri altına dönüştürdüğü halde, hayvan kemiği gibi farklı öze sahip varlıklar üzerinde aynı kesin etkiyi göstermeyebilir. Varlıklar bir aynı öze sahip varlıklarla veya kendi şeklinden olanla; latif latifle, kesif kesifle birleşir ve tepkimeye girer. $\mathrm{Bu}$ anlamda varlığın doğasını keşfetmek ve diğer varlıklarla uyumlu farklı iksirler üretmek gerektiğinden, doğal değişim, hem her tür varlığı içermez, hem her varlığın her varlığa rastgele biçimde değişmesi söz konusu olmaz, hem de değişim kuvveti içsel ve kendiliğinden değil dışsal ve amaçlıdır (İbn Haldûn, 2001, 696 vd; İbn Haldûn, 1988, C.2, 942 vd.).

Bedensel gıda olarak insan bitki ve hayvanı dönüştürüp kendine katar ancak canlılık özü olan ruh, insanda en kâmil seviyede bulunur. İnsanlar ve melekler diğer varlık türleri gibi edilgin ve ruh kabul eden bedenler değil, etkin varlıklardır. Bu anlamda İbn Haldûn'da evrim, madenden bitkiye, bitkiden hayvana dek canlı ruh vasitasıyla bedensel ve ruhsal, insandan meleğe doğru ise yalnız ruhsaldır.

Kendi içinde evrilerek bedensel ve ruhsal bir dönüşümle insanın melekler âlemine ittisali, bu noktada tasavvufta dile getirilen vahdet-i vücud düşüncesiyle benzeşmektedir. Tasavvufta vahdet-i vücûd, Hak ile yaratılmışların/halk varlıkta birliği ve bu birliğin müşahedede değil dışta ve gerçekte bulunmasıdır. Bunun için beşerî tüm varoluş hallerinden soyutlanılmalı, hissî, aklî ve hayalî varlık biçimlerinden uzaklaşılarak vücuda yaklaşmalıdır. Burada vücud, Hakk'ın vücududur (Demirli, 2012, 431 vd.). Oysa melekler âlemine geçen insanın, evrimleşerek yücelmesinin son sınırı Tanrı ile ittisal, bir anlamda Tanrısallaşması olacağından, İbn Haldûn bu düşünceye radikal biçimde karşı durur ve insanın evrilmesi/dönüşmesi sürecini, bu noktada açık ve aydınlatıcı olmayan bir düşünce, zayıf bir açıklama ve keskin bir dönüşle keser.

İbn Haldûn'a göre her varlık, değişimini bir süreç içerisinde gerçekleştirir ve tekemmül sürecinin her aşamasında farklı bir yapı ile karşılaşır. Dört unsurun farklı miktarlarda farklı 
aşamalarda bir araya gelmesi varlığ 1 tamamlar ve sürecin sonunda şey hâsıl olur. Örneğin insanın bir meni parçası iken kan pıhtısına, ardından et parçasına, bundan sonra form kazanarak cenin olmasına, bebek olarak doğup büyümesine ve gelişmesine bakıldığında, değişimin her aşamasında birbirinden farklı yapılar olduğu, doğal zaman içinde ve kendi dinamikleri çerçevesinde gerçekleştiği görülür. ${ }^{5}$ İnsan dokuz ayda, altın ise yaklaşık bin seksen yılda meydana gelir. Oluşum zamanını kısaltmak için iksir kullanmak ve maddenin yapısal unsurlarını çoğaltmak iddiası, her aşamasıyla tek tek gösterilemezse her varlık için etkili olmadığı ve ortada büyük bir sahtekârllğın bulunduğu söylenebilir. Çünkü bir varlığı meydana getirmek, bir anlamda onu yaratmak ve tüm aşamaları ve tüm nitelikleriyle ihata etmek demektir ve bu delil isteği kimyacılara karş1 en etkili itirazdır (İbn Haldûn, 2001, 721 vd.; İbn Haldûn, 1988, C.2, 967). ${ }^{6}$

$\mathrm{Bu}$ anlamda kimya, aklın iş gördüğü doğa bilimlerinden değildir ancak ruhânî nefslerin etkilerini barındıran sihir ve tılsım gibi faaliyetlerden sayılabilir. Ruhânî nefsler doğada etkindirler ve açık, bilinir ve iyi yönlü olduklarında keramet, kapalı, gizemli ve kötü yönlü olduklarında sihir olurlar. Kimya, farklı madenleri altına dönüştüren kapalı ve gizemli yapısıyla özü ve fiili bakımından sihir türünden ve bilgisi her defasında yeniden keşfedilen bir faaliyettir. Sabit kaynaklar 1şığında bir kesinliğe sahip değildir (İbn Haldûn, 2001, 695; İbn Haldûn, 1988, C.2, 940).

İbn Haldûn için şeyi kendi doğal ve olağan süreci dışında varlığa getirmek, yaratmak, değiştirmek veya dönüştürmek kuvvetine, emrine ve lütfuna yalnız Yüce Allâh sahip olsa da, eşyanın özünü değiştirmek ve onu bir halden başka bir hale döndürmek imkânı var demektir. Söz konusu lütuf dairesine peygamberlerin/enbiyâ mucizeleri ile evliyaların kerametleri de dâhildir. Mucize ve keramet dışındaki dönüştürme etkinlikleri ise ancak sihirdir. Allâh'ın insana bahşettiği ve eşya üzerinde tasarruf kuvveti sağlayan mucize, keramet ve sihir arasındaki farklara ileride değinilecektir fakat farkın temelde işlevsel olduğu ve Allâh'ın rızasına uygun kullanıldığında doğru ve hak, Allâh'ın rızasına aykırı kullanıldığında yanlış olduğu söylenebilir.

Her varlığın kendi cinsinden ve daha mükemmel olan bir üst örneği ile birleşmek arzusu içinde olduğuna musikî bahsinde de değinen İbn Haldûn, yumuşak, ahenkli ve ruhla aynı tondaki kokuların, melodilerin hatta insanların, ruha yakın geldiğini ve birleşme arzusunun böylece doğduğunu belirtir. Sevgililerin, dostların, sevilen koku veya müziklerin derin anlamı budur. Varlık veya var olmak kavramı her varlığın diğeri ile tek ortak noktasıdır ve evrendeki her varlıkta en mükemmel varlıkla imtizac ve ittihâd arzusu bulunur. Burada dile getirilen birlik düşüncesinin tasavvufî birlik/vahdet düşüncesiyle ilişkisi kurulursa, İbn Haldûn'un tasavvuf bahsinde

\footnotetext{
5'İbn Haldûn'un, insanın yaratılışına ilişsin olarak işaret ettiği âyetlerin tamamı şöyledir: Mu'minûn Sûresi, (23/12-14): "Muhakkak ki biz insanı çamurdan/tîn (gelen/alınmış) bir özden/sülâle yarattık. Sonra onu sağlam bir korunakta döllenmiş yumurta/nutfe haline getirdik. Sonra nutfeyi rahimde asılıp beslenen embriyo/alaka yaptık, alakayı şekilsiz et/mud̆̆a, mudğayı kemik yaptık ve kemiklere adale giydirdik. Nihayet onu bambaşka bir yaratık olarak inşa ettik. Yapıp yaratanların en iyisi/güzeli olan Allâh ne yücedir.” Benzer şekilde bkz. İnfitâr Sûresi, (82/7).

'İbn Haldûn'a göre, madenleri parlatarak, civa ile karıştırarak veya eritilmiş madene az bir miktar altın veya gümüş katarak zengin ve cahil Bedevîleri kandıran bu dolandırıcılarla mücadele edilmeli, bu kimselerin hırsızlık suçundan elleri kesilmelidir/hadd-i sirkat. Mâide Sûresi, (5/38) âyette: "Kadın veya erkek hırsızların ellerini, yaptıklarına karş1lık ve Allâh'tan bir ibret olarak kesin. Allâh yüce/güçlü ve hikmet sahibidir" denmektedir. Hırsızlık suçunun sübut edebilmesi ve el kesme cezasının uygulanabilmesi için suçlunun ceza ehliyetine sahip, akıllı, suçu kasıtla ve bilinçle işlemiş olması gerekir. Bu anlamda İbn Haldûn hadd-i sirkat şartlarının sağlandığı dolandırıcılığı, nitelikli hırsızlık olarak anlamaktadır. Ancak kimyacılar arasında halkı kandırmak arzusunda olmayan, yalnızca kendi ham hayalleri peşinde koşan ve bu ısrarlarını tutkuya dönüştüren kimseler de vardır. Bu kimselerinse akıl ve deney bilgisinden uzak hallerine yalnızca acınır. Kazancını çalışarak ve kendi emeğiyle elde etmek irade, kuvvet ve imkânına sahip olmayan aciz ve güçsüz kimselerin meylettiği sihir veya kimya, fakirin ekmeğidir. Örneğin gündelik geçimini sağlamakta zorlanan Fârâbî iksirle altın elde etmeyi mümkün görürken, varlıklı bir kimse olan İbn Sînâ buna inanmaz ve reddeder. Dolayısıyla İbn Haldûn'a göre toplumsal şartlar, yaşam şartları ve özellikle maddî yetersizlik, sıradan insanı da filozofu da olmayacak şeye inanır hale getirebilir. Sihirli bir iksirle sıradan ve değersiz bir madenin altına dönüştürülebileceğine bel bağlamanın toplumsal yaşam ve ekonomik şartlara bağlanması ilginç ve dikkat çekicidir. Demek ki bu türden imkânsız bir umut, asıl olarak güçlükler karşısında insanı ayakta tutan ve şevke getiren psikolojik bir kuvvettir (İbn Haldûn, 2001, 721 vd.; İbn Haldûn, 1988, C.2, 964-5).
} 
reddettiği bu düşünceyi, musikî bahsinde kısmen kabul ettiği düşünülebilir (İbn Haldûn, 2001, 534; İbn Haldûn, 1988, C.2, 756).

$\mathrm{Bu}$ bağlamda İbn Haldûn varlıkların değişimleri/changement ve birbirlerine dönüşümlerini kimyada kabul eder. Ancak bu değişim süreci tek yönlü, gelişmeye dönük ve sınırlıdır ve her madde için geçerli değildir. Darwin'in değişim ilkesi ise çift yönlü ve yalnızca ilerlemeye dönük değil gerilemeye de açıktır, dolayısıyla bu ilke bakımından iki düşünür birbiriyle uyumlu değildir. Ayrıca İbn Haldûn'a göre varlıkların evrimi rastgele değil, sadece kendi ufuklarına komşu ufukların yakın üyelerine dönüktür. Böylece aralarındaki anatomik farklara rağmen, kesif varlık latif varlığa, temelde ruhî varlık olan insan meleğe dönüşebilir. İbn Haldûn'un değişim ilkesi, içerdiği örtük bir planlama ve varlığın gelişip yücelmesi amacına dönük olma özelliğiyle, evrimde amaçlılığı reddeden Darwin'le uyumlu değildir (İbn Haldûn, 2001, 719; İbn Haldûn, 1988, C.2, 962).

\subsection{Tasavvufta Evrim veya Evrimin Yöntemi}

Tasavvuf, İbn Haldûn'a göre İslâm'da sonradan ortaya çıkan naklî bir ilim, züht ve ahlâk odakl1, ibadet yoğunluklu, dünyevî güzellikleri ve rahatı terk ederek günahlardan ve halktan tümüyle uzak bir yaşamın benimsendiği bir disiplindir. Tasavvufun bu yönlerini beğendiği halde, vahdet-i vücud düşüncesini onaylamaz. Ona göre halktan uzaklaşıp ibadete yönelerek ruhsal ve dînî mertebeleri zamanla aşarak nihayet en üst mertebe olan 'Allâh'tan başka ilah olmadığına şahadet etme/tevhîd ve irfan makamına ulaşan mutasavvif/zâhid, Hz. Peygamber ve sahabenin yolunu takip eden kimsedir. Bu mertebeleri elde etmelerinde sabır, şükür, kabz, bast, ferah, hüzün, rıza, gadap gibi haller etkilidir. Fakat bu hallerden evvel ve bunlarla birlikte imanın bulunmas1 zorunludur çünkü hepsinin kökü itaat ve ihlâstır. Böylece tasavvuf, ibâdâtın kusurlardan temizlenmesi, riyazetle ruhun arındırılması, nefs muhasebesi ve mücâhededen doğan ruhî bir zevk haline gelir. Ahlâkî bir yönelim olarak tasavvuf, Gazâlî’nin ince ve derinlikli tetkikleri sonucunda dînî bir ilim halini almış, kulun göğsünden/sadr çıkıp/sudûr bireyselliğini aşarak yazılı/sutûr ve aktarılabilir bir yapıya kavuşmuştur.

İbn Haldûn'a göre Asr-1 Saadet ve Emevîlere dek süren dönem, İslâm'ın bedevîlik dönemidir. Emevî devlet ve siyaset tarzının etkisiyle hadarî yaşam tarzı ortaya çıkınca, Müslümanlar arasında bedevîliğin izleri silinmiştir. Tasavvuf da ilk olarak, Hz. Peygamberin bıraktı̆ğ mirasa sade, gösterişsiz ve içten biçimde bağlı kalmak ve zühd içinde yaşamak arzusu duyan sahabe arasında ortaya çıkmıştır. Dolayısıyla sûfî yaşam tarzı, yeni bir oluşum olarak bir farklılaşmanın değil tersine aynılaşmanın veya öze uygunluğun bir ifadesidir/yorumudur. Çeşitli özellikleriyle genel anlamda bedevîliği hadarîliğe tercih eden İbn Haldûn, bedevîliğin bir ürünü olan işte bu erken dönem sûfî yaşam tarzını övüp yüceltmekte, sonradan ortaya çıkan hadarî yaşam ve onun ürünü vahdaniyetçi tasavvufu reddetmektedir.

İnsan evreni dışsal olarak duyu algısı ile kavrar, içsel olarak ruhuyla keşfeder. Dışsal ilgileri süre giden kimsenin içsel kuvvetleri ve ruhu zayıftır. Tersine dış dünyaya duyusal ve bedenî ilgilerini azaltıp düşünen ruhu beslediği ölçüde kişinin iç dünyası zenginleşir, ruhsal kuvvetleri yükselir. ${ }^{7}$ Bu yükselişle mutasavvıf ruh, melekî âlemi keşfe dalar, ilahî lütuflara ve ledünnî ilimlere doğru açılır ve varlığın hakikâtini elde eder. Bu makamlarda sûfî, gerçekleşmeden evvel olayların seyrini bilmek, sıradan varlıklar üzerinde tasarrufta bulunmak ve diğer nefislerin kuvvet ve varlığını kendi yüksek kuvvetlerine itaat ettirmek türünden kerametlere sahip olur. Böylece önündeki perde/hicâb kalkar/keşf ve gayb âlemini kendinde seyre dalar. $\mathrm{Bu}$ anlamlarıyla söz konusu yükseliş kimyada sözü edilen, insanın kendi yapısından farklılaşıp dönüşerek ruhen evrimleşmesinin bir formu kabul edilebilir (Kısmen özetlendiği haliyle bkz. Gazâlî, C.3, 2012, 53 ve Riyazetu'n-Nefs).

\footnotetext{
7 “İçimden Şu Zalim Şüpheyi Kaldır” şiirinden (1975) İsmet Özel’in diliyle söylersek: "İnsanlar/Hangi dünyaya kulak kesilmişse öbürüne sağır/O ferah ve delişmen birçok alınlarda/Betondan tanrılara kulluğun zırhı vardır." (Özel, 2017, 197).
} 
İmanın gerekli şart olmadığı keşf yolu, İbn Haldûn’a göre yalnızca mutasavvıflara özgü de değildir, yoğun açlık ve riyazet durumunda büyücülere, sihirbazlara, falcılara veya gayrî Müslimlere de açıktır. Fakat iman elde edilen bilginin doğru biçimde kullanılabilmesini sağlar. Dolayısıyla tasavvufta önemli olan keşfe nail olmak değil bunu istikamet üzere riyazet ve ibadetle elde etmektir. Mutasavvifların riyazet, ibadet ve amelle örülü bir hayatı, ruhsal arınmayı, temizliği, bunu ruhsal boyutlara taşıyarak derin bir biçimde yaşamayı, Allâh'a, kullarına ve tüm diğer varlığa karşı en açık ve içten bir tavırla hareket etmeyi benimseyen bu yaşam biçimi, her yönüyle beğeniye değerdir. Ancak sâlik bazen kendisini tüm varlıkla ve evrenle birlik/cem " halinde bulur. Burada kalması sakıncalı olduğundan derecesini yükseltmeli ve ayrılık/fark makamına çıkmalıdır. Bu ilerleyişin sonunda ise insan, melekler âleminin nihayetinde Bir'le bir olmak imkânını bulur. İşte İbn Haldûn'un, ittihatçı mutasavvıflar olarak adlandırdığı kimselerle yaşadığ 1 düşünsel ayrılık kendisini bu noktada gösterir. Tasavvuf yolunun vicdanî ve kalbî sonuçları genel itibariyle aklın değil batınî hislerin etkinlik alanına girdiği halde, Allâh'ın evrenle ve insanla ittihadı tümüyle ortak duyusal tecrübe ve aklî delillendirmenin dışındadır, bu anlamda ileri sürülen düşüncelerin reddiyle kabulü birbirine denktir. Buna göre, sonsuz ve kadim bir varlığın sonlu ve hâdis bir varlığa enkarne etmesi, tasavvur etmesi zor bir görüştür. Fakat bu düşünce aynı zamanda hem Tanrı'nın kendisini Hz. İsâ'nın bedeninde var etmesi hem de İmamiye Şiîliğinin masum imam düşüncesine benzemesi bakımlarından da kabul edilemez. Evrenle birliğin duyu, idrak veya akıl ile olduğunu ileri süren panteist düşünürler, $\mathrm{O}$ olmadan varlığın ayakta kalamayacağını ileri sürerler ve muhdes varlı̆̆ kadim varlı̆̆ın mazharları olarak kabul ederler. Râfizî Şiîliğe göre Allâh, masum imamın bedenine hulûl eder ve onunla bir olur. Böylece imam ilahlaşır. Tasavvufta kullanılan kutb kavramı, masum ve ilahî imam inancının yerini alır. Buna göre âriflerin reisi hayatta kaldığ 1 müddetçe kendisine denk bir varlık bulunmaz ve ruhu kabz edildikten sonra yerine varisi geçer. Bu yaklaşımı İbn Sînâ'nın da el-İşârât'ta kabul ettiğini belirten İbn Haldûn, giderek Râfizî düşünceyle karıştığından dolayı vahdet ve keşf düşüncelerini reddeder (Kısmen özetlendiği haliyle İbn Haldûn, 2001, 611-5; İbn Haldûn, 1988, C.2, 853-9).

İbn Haldûn tartışmayı Allâh ile evren arasındaki ilişki üzerinden de ele alır. Allâh'ın evrenden ayrı mı/mübâyenet, (İbn Haldûn, 1988, C.2, 854) yoksa onunla birleşik mi/muttasıl olduğu meselesinde fikıh mekânda ayrılığı benimser, kelam Allâh'ın evrenden ayrık veya ona birleşik olduğunun söylenemeyeceğini ileri sürer, felsefecilerse O'nu evrenin içinde veya dışında kabul etmezler. Tasavvufta Allâh evrendeki varlıklarla birdir, bu birlik ya Allâh'ın onlara enkarne/hulûl etmesiyle ya da onların ta kendisi olmasıyla mümkündür. Dolayısıyla tasavvuf düşüncesinde ister tümel ister tikel mânâda olsun, evrende Allâh'tan başka bir şey var değildir (İbn Haldûn, 1988, C.2, 853 vd.). İbn Haldûn içinse ayrıklık veya birleşiklik ancak mekânda söz konusu olduğundan ve Allâh'a da bir mekân atfetmenin imkânı olmadığından, Allâh'la evren arasında bu türden bir ilişkiden söz edilemez. Felsefede sözü edilen Allâh'ın evrene içkin veya onu aşkın oluşu da böyledir. Allâh zatı, özü, nitelikleri ve varlı̆̆g ile tüm evrenden ayrıdır. Bunun zıddı ancak birlik/ittihad olabilir ve Allâh ile ittihad bu yönüyle de mümkün değildir (İbn Haldûn, 1988, C.2, 854).

Buna karşın İbn Haldûn yukarıda eleştirip reddettiği evtâd ve abdâl kavramlarını Mısır'da Sultan Berkûk Hankâhı'nın açılış konuşmasında kullanmıştır (İbn Haldûn, 1998, 1111; İbn Haldûn, 2011, 183). Yine daha önce Bir/Allâh ile bir olma düşüncesiyle birlikte ele aldığı ve reddettiği keramet konusunu, tasavvuf bahsine sonradan yazdığı anlaşılan zeyl ile kısmen onaylamış ve mutasavvıfın âleme tasarruf etmesi, kerametleri ve gaybtan haber vermesi gibi hususları da hakikât kabul etmiştir. Kelamcıların kerameti reddetmesinin sebebi, ona göre mucize ile karıştırılması olabilir ancak bu problem, peygamber ile veli arasındaki ontolojik ve epistemolojik farkların serimlenmesiyle ortadan kalkar. Peygamberin mucizesi vahiyle gerçekleşir, meydan okuma veya önceden haber verme/tahaddi içerir ve yalancının yalan sözünü tasdik için kullanılamaz. Mucize, peygamberin doğru sözünü tasdik eder ve bu söze aklî biçimde delalet eder. Velinin ise keramet göstermek imkânı kendi elinde değildir, keramette tahaddi bulunmaz ve hem keyfiyeti hem kemiyeti bakımından mucizeye oranla daha aşağıdadır (İbn Haldûn, 1988, C.1, 279). Bunlardan hareketle İbn Haldûn'un, Mağrib’te bulunduğu genç 
yaşlarında, bilgisinin de zayıflığıyla reddettiği tasavvufu, bilgi ve tecrübesi geliştikçe kabule yaklaştığı görülmektedir. O kadar ki Fromherz, onu hal ve tavırlarıyla pek çok açıdan sufî olarak tanımlar (Fromherz, 2018, 86).

İnsanın evrimleşerek melekler âlemiyle ittisaline imkân veren tasavvufî yollar temelde ikidir. İlki, akla dayalı bireysel gayrettir. Burada etkin kuvvet ferdin kendi başlıca içsel kuvvetleri, akıl ve okuduklarını anlama ve uygulama yeteneğidir. Bu yolda a) bu kuvvetler her akıl ve irade sahibinde ortak olarak bulunur. Bu anlamda isteyen ve yönelen her sâlik, yolu kendi başına baştan sona kat etmek ve Allâh'a ulaşmak kudretine sahiptir. Allâh'a ulaşmanın imkânı akıl ve iradede olduğundan bu metotta bir mürşide ihtiyaç duyulmaz. b) Bu metotla ulaşılan Allâh tasavvuru akılsaldır. İkincisi ise kâmil ve tecrübeli bir mürşidin rehberliğidir. Önünde yol gösterici bir rehber olmayan sâlik, tecrübesizliğinin bir sonucu olarak hatalı yollara savrulup hedefinden uzaklaşabilir. Ancak mürşidin tecrübesi, kemali ve yetkinliği bir ön kabulden ibarettir. Çünkü sâlik, mürşidin seviyesini belirleme gücünü haiz değildir. Tasavvuf her ne kadar içsel ve ferdî bir tecrübenin hakikâti olsa da, bir mürşidin rehberliğinin kabulü ile objektif, nesilden nesle aktarılan ve sabit/skolâstik bir ögreti halini alır. Bu metotta akla ve iradeye başvurulmaz, benlik ise bask1lanmas1 gereken bir ögeye/nefs dönüşür (İbn Haldûn, 1998, 79).

Dolayısıyla İbn Haldûn'a göre insanın tek yol göstericisi Allâh'tır. Değerlendirme, tefrik, temyiz, ilim ve mârifeti tahsil etme kuvvetleri aklın doğasındadır. Akıl, düşüncesine Yaratıcıyı konu edinir, O'nun varlığının delillerine ve mükemmel bilgisine ulaşmak arzusu ve amacıyla kuvvetlerini harekete geçirip ardı ardına akıl yürütmeler ve çıkarımlar yapar. Bu hususta diğer organlarda olmayan türden bir kuvvet ve hıza sahiptir, yorulmaz ve hızı kesilmeksizin bir anlık sürede sayısız akıl yürütmeyi yapar, amacına ulaşmak için düşünceyi tamamlamaya ve mükemmelleştirmeye çabalar. Namaz, oruç, Hac vb. bedensel/zahirî ibadetler yanında, imana özgü bazı husus ve sıfatlar gibi içsel/kalbî veya bâtınî kaynaklar aklı tamamlayan kaynaklardır. İçsel sıfatlar iffet, sabır, hayâ gibi olumlu ve iyi olabildikleri gibi riyâ, haset, kin ve kibir gibi olumsuz ve kötü de olabilir. Bu kaynaklarla insan bütüncül bir varlığa dönüşür. Zahirî amellerin yönünü Bâtınî ameller belirlediğinden, zahirî amellerden daha önemlidirler. Vücuttaki bir et parçasının iyi olmasının tüm vücudu iyi etmesiyle onun kötü olmasının tüm vücudu kötü etmesi (Buhârî ; İlm, 39; Müslîm; Mûsâkât, 20; İbn Mâce; Fiten, 14; Ahmed b. Hanbel; Müsned; IV, 270.) hususundaki hadis de kalp ve burada ortaya çıkan iman hareketiyle ilgilidir (İbn Haldûn, 1998, 82). Kalbin ve aklın gösterdiği amelleri bedensel olarak tekrarlamak bu fiillerin nefste yerleşmesini sağlar. Nefste sağlam biçimde yer eden ve alışkanlık halini alan fiiller, geri dönerek daha çok tekrar edilir ve sonuçta ortaya çıkan hidâyetin etkisiyle, nefse başlangıçta zor gelen fiiller giderek kolaylaşır ve pekişir. Dolayısıyla fiillerin başlangıcı bedenî organlar gibi görünse de onlara bu itkiyi veren kalptir. Bu temrinleri aralıksız gerçekleştiren herkes, arzu ettiği amaca ulaşır. Ancak kalpte ve akılda ortaya çıkan hallerin bazıları ilerlemeyi ve yükselmeyi sağladığ 1 halde, bazıları mutsuzluğu getirebilir. İçsel ve dışsal tüm fiiller buna tabi olduğundan, hangisinin terk edilip hangisinin beğenileceği ancak şeriâtle bilinebilir (İbn Haldûn, 1998, 84). Tüm amellerin başı olan iman, işte bu yüzden bütün mutlulukların en yükseğidir. Buna karşın batınî amellerin denetlenmesi ve kontrol altında tutulması güç olduğundan ara verilmeksizin bask1 altında tutulması gerekir. Bunun bilgisine ancak Allâh ve Peygamberi vâkıftır. Bu anlamda insanın, kalbini istikamet üzere biçimlendirmesi ve bedeni ile uyumlu hale getirmesi ancak onların ilahî yönergeleri ve uyarıları ile mümkündür (İbn Haldûn, 1998, 87). Mutasavvıflar, işte bu kuvvetlerini kullanarak yükselir, ruhen incelir ve insanlık vasıflarını aşarak melekler âlemine ittisal ederler. Bu birleşme vahiy alma türünden değil ilham alma, ses duyma kısmî ve çoğu kere sistematik olmayan görüntüler görme biçiminde hâsıl olur. Bu süreçte ortaya çıkan keramet, keşf, $s e k r$ ve gaybet halleri sâlikin kendi isteğiyle değil, Allâh'ın bir lütfu olarak ortaya çıkar. Dolayısıyla mutasavvıfların, aklın ortadan kalktığı vecd esnasında keşfettikleri çoğu kere din dişı şeyler ve söyledikleri sözler/şatahât mazur görülmelidir. Bu söz ve halleri sorgulamak aklın başa çıkabileceği şeyler değildir, üzerlerinde daha fazla söz sarf etmemelidir (İbn Haldûn, 2001, 611, özellikle 616; İbn Haldûn, C.2, 1988, 849, özellikle 853). 


\subsection{Evrimle İlgili Diğer İlimler}

İbn Haldûn insanın evrimini bunlardan farklı ilimlerle de ilişkilendirir ve bu ilimleri esas itibariyle gaybı bilmek ve gelecekten haber vermek yönleriyle ele alır. Bunlardan biri gerek bireysel gerek devlet yaşamı düzeyinde ilgi uyandıran gelecekten haber verme/cefr ilmidir. Olayları hakikâtte olmadan evvel bilmek arzusuyla dolu kimselerin desteğiyle hadarî umrana özgü kâhinler, falcılar, müneccimler veya rüya tabircileri ortaya çıkar ve bunların şehir hayatındaki yer ve önemi inkâr edilemeyecek denli büyüktür. Şer'î ilkeler bakımından varlığı tartışmalı olan bu ilimler toplum yaşamının bir realitesidir. Gelecekten haber vermeye hadasân, şiir biçiminde ve şifreli yazım tarzına melhâme ve bu işle uğraşanlara kâhin veya arraf denir.

$\mathrm{Bu}$ yöntemlerin en ünlüsü; kelimeleri oluşturan harflerin sabit sayısal değerinden hareketle kelimenin gizli anlamlarını çıkarsama yöntemi olan cefr veya cifrdir. Bu harf hesabına, çoğu kere Kur'ân-1 Kerîm'de yer alan hurûf-u mukatta', bunların sayı değerleri ve dört unsur da eklenir. Cefr ilminin kökeni olarak Câfer-i Sâdık'tan rivayet edilen, içerisinde Kur'ân'ın tefsîrine yönelik batınî bir takım anlamlar ve gelecek olaylara karşı yakınlarına uyarılar içeren, orijinalitesi ve güvenilirliği şüpheli bir eser gösterilir. Ancak İbn Haldûn'a göre bu şüphe yalnızca eserle ilgilidir. Çünkü evliyâ keramet gösterebildiğine göre, Hz. Peygamberle doğrudan bağı olmadığı halde ehl-i beytten olan Cafer-i Sâdık da bu türden bir mucize gösterebilir ve gelecekten haber verebilir. Buna karşın bu ilimler aklen tutarsız olduklarından hakikâtin bir delili olamaz. Cefr ilmine bedevî umranda iltifat edilmez, hatta doğrudan hadarî umrana dâhil edilen cefr, hadasân ve melâhim esas itibariyle umranın bozulma göstergelerinden sayılır.

Müneccimler gelecekten haber verme işini yıldızlara bakarak, güneşin ekinoks üzerindeki yıllara yayılan hareketinden/kıran çıkarsayarak ve bir takım hesaplamalar sonucunda yaparlar. Altmış yıllık döngü küçük, iki yüz kırk yıllık döngü orta ve dokuz yüz altmış yıllık döngü büyük kıran olarak adlandırılır. Küçük kıran âsilerin zuhûruna, şehirlerin ve umranın harap olmasına, orta kıran devleti genel olarak tehdit eden grupların varlığına, büyük kıransa mülkün el değiştirmesi, asabiyyenin bir kavimden diğerine geçmesi gibi büyük iş ve olaylara delalet eder.

Yıldız dereceleri, açıları ve harf hesapları üzerinden geleceğe dâir bilgi çıkarsamak işinde Cirâş b. Ahmed Hâsib, Ebû Ma'şer ve Hârûn Reşid ve el-Me'mun'un müneccimliğini de yapmış olan ünlü İslâm filozofu Kindî ustalaşmıştır. Kindî’nin cefr adında bir kitabından bahsedilse de eserin varlığına ilişkin kesin bir delil bulunmamaktadır. İbn Arabî ise Mısır'dayken, içerisinde karışık ve anlaşılmaz sözler bulunan böyle bir eser kaleme almıştır. Bu müneccimlerin bir kısım kehanetleri yanlış çıksa da, Abbasî hilâfetin sonlarında kuzey doğudan Türklerin gelip devlete gâlip olacakları ve ileride Rum illerini de ele geçirecekleri türünden doğru haberleri de olmuştur. Kâhire'nin ömrünün 832 yıl olacağına ilişkin hesaplar da ciddiye almaya değerdir. İbn Haldûn'un bu bahiste ismini andığ İ́bn Sînâ ve İbn Akb'a nispet edilen eserlerse yalnızca kıranlara ilişkin astronomik bilgiler olup müneccimlikle ilgili değildir. Esasında geleceğe dair haberler içeren şifreli melhâmeler uydurmak ve bunlara meraklı kimseleri kandırmak o kadar da zor olmasa gerektir. Bu anlamda İbn Haldûn'un cefre ilişkin düşünceleri kesinlik arz etmez (İbn Haldûn, 2001, 411-6; İbn Haldûn, C.1, 1988, 604-10).

Söz konusu bu sapkın ilimler yanında peygamberlerin, velilerin ve ilahî rüya görenlerin halleri haktır (İbn Haldûn, 2001, 415; İbn Haldûn, C.1, 1988, 611). Ona göre peygamberlerde, sıradan beşerî haller dışında ilahî bir takım hal ve eğilimler vardır. Öncelikle diğer insanlarla ortak olan şehvet, arzu, gadap ve hırs gibi duygularında rabbânî bir yön ve kontrol hâkimdir. Bu yönlerde değişim gözlenmez, rabbânî cihet her an muhafaza edilir ve davet, Tanrısal yola kolaylıkla ve güçlü bir biçimde gerçekleştirilir. Ayrıca sıradan insanların bilmelerine imkân olmayan gayb alanına Allâh'ın lütfuyla ancak peygamberler nüfuz edebilir. Genel mânâda her insanın özü itibariyle melekler âlemiyle bağlantı halinde olduğu düşünülebilirse de, İbn Haldûn bu hâli yalnızca peygambere ve velilere has kabul eder. Buna kisaca vahiy alma veya ilham denir. Vahiy ve ilhamla ilahî bilgi, beşerî idrak seviyesine iner (İbn Haldûn, C.1, 1988, 276). 
Peygamberlerin ortak özellikleri günahtan korunmuşluk/ismet, iffet, yüksek ahlâk sahibi olmak, dürüstlük, kulluğa davet/ibadet, toplumda asalet, saygınlık ve itibar sahibi olmaktır/haseb. $\mathrm{Bu}$ anlamda peygamberlik için kişisel hasletler yanında umran teorisinin önemli kavramlarından asabiyye de çok önemli bir yere sahiptir. İçinde bulunduğu toplumda etkinliğini en üst seviyede gerçekleştirebilmek için peygamberin asalete, güçlü bir asabiyyeye ve iktisadî güce sahip olması gerekir. Dolayısıyla peygamberlik, rastgele bir seçim olmanın çok ötesinde ilahî bir hikmete ve akılla kavranabilen toplumsal hakikâtlere dayanır. Böylece toplumunun en saygın ve servet sahibi bir üyesi olmak peygamberi zorluklar karşısında daha güçlü kılacaktır (İbn Haldûn, C.1, 1988, 279).

Vahiy almanın mükemmeliyetine ulaşamayan, bir takım sözler, ayna, su tası, şeffaf cisimler, kemik veya hayvan gibi bir yardımcı kuvvet vasıtasıyla gerçekleşen kehanette, vahye benzer gaybî bir bilgi amaçlasa da, bu bilginin ancak başlangıcına nüfuz edilir. Kendinde ve son derecede gelişmiş bir tahayyül kudreti olan kâhin, peygamber gibi küllî bir nüfuz kuvvetine sahip olmadığından ancak cüz'iyata muttali olur. İnsan türü içinden çıkan ruhen gelişmiş üyelerden biri olan kâhin, bu anlamda velilerle benzer seviyede bulunur. Ancak elde ettiği bilgi, tam ve kâmil ilahî bir bilgi değil, eksik ve sınırlı şeytanî bilgidir. Kullanılan yöntem dolayısıyla kehanetin bir kısmı doğru bir kısmı yanlıştır, vahiyse tümüyle doğru, tam ve kâmildir (İbn Haldûn, C.1, 1988, 291).

Hz. Peygamberin, peygamberliğin kırk altı cüzünden biri olarak saydığı rüya (Kütüb-i Sitte, C.4, 10) ${ }^{8}$ doğru, haberci veya sahih/ruya-yı sâdıka biçimiyle gayb âleminin bilgi kaynaklarından biridir. İbn Haldûn da rüyayı şer'î ilimlerden kabul eder. Uyanıkken bedenle ve duyu algısıyla meşgul olan akıllı ruh, bir idrak faaliyeti olarak, bedenin uykuya geçmesiyle serbest kalır ve ilahî idrak perdesinin ötesine geçerek hakikâti kendinde seyre dalar. Bu seyir, tam veya anlık olabilir. Elde edilen idrak nesneleri muhayyile kuvveti ile hayallere dönüştürülür, böylece zihin bu idrak nesnelerini cisimselmiş gibi görür. Buna rüya denir. Aklî ruhtan muhayyileye inen suretler sadık/salih/doğru iken, gündüz yaşanılan şeylerin muhafaza edildiği hafızadan muhayyileye iletilen suretler karışı/aldatıcıdır. Hemen uyanmak istenilen rüyalar veya görülen suretlerin hatırlamaya çalışmayı gerektirmeyecek denli sabit olanları sadıktır. Aldatıcı rüyalar ise hafızaya zamansal olarak işlendiğinden kısım kısım hayale gelir ve karma karışık bir hal alabilir. Dolayısıyla kişi uyandığında hatırlanmayan yahut detayları giderek silinen rüyalar aldatıcıdır. Rüyalar Allâh'tan, melekten ve şeytandan olmak üzere üçe ayrılır (Kütüb-i Sitte, C.4, 507, C.17, 512). Rüyada aklî ruhun idrak ederek muhayyileye devrettiği bilgilere, muhayyile gerçeğe az çok denk düşen kendince temsiller verir. Örneğin sultanlığın temsili deniz, düşmanın remzi yılandır. Allâh'tan olan rüyalar sadık olduğundan tabire ihtiyaç duyulmaz. Melekten olan rüyalarda sadık oldukları halde tabire ihtiyaç duyulur. Şeytandan olanlarsa aldatıcıdır ve ruya-yı edğas denir (Kütüb-i Sitte, C.4, 515; İbn Haldûn, 2001, 625; İbn Haldûn, 1988, C.2, 866). İbn Haldûn'a göre rüya, nefs-i nâtıkânın olayların yansımasını kendi zatının ruhaniyetinde bir an için görmesi olduğundan, insan ruhunun hayvanî tarafinda böyle bir yetenek yoktur, ruhanî nefsin manevî yanı kuvvetlendikçe olaylara ilişkin suretler onda yer almaya başlar. Ruhanî ve bilkuvve bir yapıda olan ruh, kuvvetlerini fiile döndürdüğünde bedenin bağlarından, araçlarından ve idrak vasıtalarından kurtulur ve meleklerin yer aldıği rûhâni evreni doğrudan deneylenmeye başlar. Ancak bedensel araçlarla kâim olduğundan, kendinde ruhanî olan meleklerden daha aşağ seviyede olacaktır. Dışsal duyu algısından veya cismanî hallerden uzaklaşmış herkeste bu hal bilfiil mevcuttur ancak veliler ve sıradan insanlar için iki farklı türdür. Uyku hali işte ruhun, ruhanî âlemi deneyleme, geleceğe dönük bilgi elde etme ve ruhaniyete bir anlık da olsa erişme hâlidir. Eğer elde edilen bilgiler açık ise, tabire gerek duyulmaz, tersi bir durumda ise bilgilerin açık bir zihinle kavramlaştırılması gerekir (İbn Haldûn, 1988, C.1, 295). ${ }^{8}$ Hadisin tamamı şöyledir: "Zaman (ahret) yaklaşınca, mü’minin rüyası neredeyse yalan söylemeyecek. Esasen
mü'minin rüyası, peygamberliğin kırk altı cüzünden bir cüzdür." 
İbn Haldûn için insanlar âleminin en üst noktasında fakat kâhinlerden daha aşağı seviyede bulunan ve melekler âlemiyle/ufuk-ı a lâ ittisal etmek istidadına sahip diğer bir grup kimse arraflardır. Bunlar su, ayna veya kemiklere bakanlar/nâzır/falcı, hayvanların seslerinden anlam çıkaranlar/ehl-i zecr ve çakıl taşları veya tohumları birbirine vurarak anlam çıkaranlar/ehl-i tark olarak da bilinirler. Bu grubun kullandığı araçlar doğrudan bilgi elde etmeye yaramadığından, arraflar ses ve görüntüleri yorumlarlar. Mecazî bir takım sözlerle gaybtan haber verenler/mecnûn ve uyku halindeki veya ölmek üzere olan kimselerden bir takım haberler alanlar/nâim veya meyyit da vardır. Mecnunlar, nefs-i nâtıkalarının bedenleriyle olan ilgisi zayıf veya bozuk olduğundan, çoğu zaman bilinçli olmayarak gayba dair şeyler söyleyebilirler ancak bu sözlerin hayvanî/şeytanî olması mümkündür. Onların dînî mükellefiyetleri üzerlerinden kaldırılmış ancak insanlık ve benlik bilinçleri sabit bırakılmıştır. Böylece ibadet ve zikir gibi dînî yönelimlerini tam ve doğru yapamazlar, delilerin ise bu türden dînî yönelimleri hiç yoktur. Uykuya geçerken, sayıklama veya -çoğu kere kafası vücudundan ayrıldığı ve ölümün çok yakın bulunduğu anda- insanın iradî olmayan bir tarzda gayba dair verdiği haberler doğrudur. Çünkü bu anlarda cismanî nefsin etkisi ortadan kalkar, kişi gayb âleminin sınırında bulunur ve sözüne şeytanî unsurlar karışmaz. Mutasavvıflar da bedenlerini açlı̆̆a maruz bıraktıkları yoğun bir çile çıkarma devresinin ardından gayba muttalî olurlar. Zikir ve ibadetle desteklenerek nefsin şeytanî etkilerden uzaklaştırılıp ilahî olana yöneltildiği bu yoğun riyazet ve açlık, bedeni ölümle karşı karşıya bırakır ve ölüm anındakine benzer bir hal teşekkül ettirilir. Gönüllerde olanı bilmeye keşff, eşyaya tasarruf edip gaybdan haber vermeye firâset ve kendi için tasarrufta bulunmaya keramet denir. Gayba muttalî olmak, irfan ve hikmete ulaşmak için geliştirilen tüm yöntemler arasında en doğru olanı budur. Bunların da arasında meczûp/buhlûl/behlül denilen bir grup bulunur ki bunlar Allâh'ın fazlı ve lütfuyla velilik makamına yükselirler. Onların gayba ittisali sağlıklıdır çünkü nefs-i nâtıkaları ne mecnunlar gibi bozulmuştur ne de deliler yok olmuştur (İbn Haldûn, 1988, C.1, 299).

Hesâbu'n-nîm gaybı bilmek iddiasıyla, ebced hesabına ve isimleri meydana getiren harflerin kendilerine karşılık gelen rakamları belirli toplama-çıkarma işlemlerine maruz bırakmaya dayanarak geleceğe ilişkin tahminde bulunur. Bir başka yöntem ise, zâyircedir/zâirece/zâyircetu'l-âlem. Büyük bir dairenin içine çizilmiş ve felekleri, burçları, unsurları, ruhaniyeti, ilimleri vs. temsil eden daha küçük paralel dairelerin oluşturduğu bir cetvel kullanılarak sorulara cevap aranır. Burada da yine kısmen ebced hesabına başvurulduğu görülür (Mes ‘ûdî’nin Mürucu'z-Zeheb'inden naklen İbn Haldûn, 1988, C.1, 301 ve 315).

Bu ilim ve faaliyetlerin umranda ve İbn Haldûn'un düşüncesinde yer etmesinin sebebi, insanın ruhsal evriminin çeşitli yöntemleri olarak kavranmalarıdır. Bunlar arasında peygamberlerin, velilerin ve mutasavvifların vahiy, ilham, riyazet ve rüya gibi faaliyetleri, doğruluğu bakımından şüphe götürmez. Kâhinler, ehl-i tark, falcılar ve mecnunlar, âlem-i gayda ittisalde tam ve kâmil olmadıklarından, ilettikleri bilgiler ne tam doğrudur ne de tam yanlıştır. Arraflar, müneccimler, kum falcılar1/hattu'r-reml, ebced hesabı ve zâyirce gibi kişi ve yöntemlerse gayba ittisal edemediklerinden, kendi hislerini, zanlarını ve tahmine dayanan vehimlerini dile getirmektedirler (İbn Haldûn, 1988, C.1, 302).

Gaybdan haber verme sanatı olan bu meslekler, İbn Haldûn'a göre umran olan her yerde çoğalır. Oysa gayba nüfuz etmek sanatla/meslekle olmaz. Duyusal âlemden ruhsal âleme dönme hassası kendilerinde yaratılış icabı bulunan kimseler müstesna, bu bilgiyi teknik bir yolla elde etmek kimse için mümkün değildir. O kadar ki buhlûller gibi ibadet şartı kaldırılanlar için ibadet bile bir vesile değildir. Bu anlamda gaybı bilmek hassası olmayanların yaptıkları şeyler, nazarî/teorik ve amelî/pratik bir değer taşımaz, onların üstü kapalı ve şiirsel ifadelerine yalnızca yeterince bilgi sahibi olmayan kimseler inanır. Matematiksel bilmeceler/lugaz ise bir miktar sayı bilgisiyle kolaylıkla çözülebilir. Ortaya çıkan sonuçların doğru olanları ancak tesadüf eseri olabilir (İbn Haldûn, 1988, C.1, 312, 317).

Geleceğe ilişkin gâipten haber vermenin şartı, esasen o haberin veya olayın şartlarını hazırlayan tarihsel, siyasal veya toplumsal sebeplerin bilinmesidir. Dolayısiyla gelecek olayları bilmek, İbn Haldûn'a göre, tarih ve toplum metodunun bir gereği ve uzantısıdır. Topluma özgü 
bir olayın geçmişte ortaya çıkma sebepleri tetkik edilip günde varlığı belirlenebilirse, benzeri bir olayın ortaya çıkıp çıkmayacağı tahmin edilebilir. Bu; kehanet, falcılık, müneccimlik, arraflık, rüya görme veya vahiy almayla ilgili bir durum değil, ilmî bir tahlil ve araştırma yöntemidir.

\section{Sonuç ve Değerlendirme}

İbn Haldûn'un evrim anlayışı, Endülüs’te yaygın bir etkiye sahip olan İhvân-1 Safâ ve İbn Miskeveyh'ten mülhem görünmektedir. Ancak İbn Miskeveyh'te yer almayan insanın melekler âlemine evrimine ilişkin düşünceler İhvân'da yüzeysel biçimde yer bulur. Risâleler'de hayvanlar âleminin çeşitli üyelerinin farklı türden özelliklerini geliştirmek suretiyle insanlar âlemine geçtiği ve bunu maymunların bedensel özellikleri, atların huyları, fillerin zekâları, papağan ve bülbüllerin müzik yetenekleri ve arıların kendilerine has sanatları ile başardıkları vurgulanır. İbn Miskeveyh ise varlığın, bir bütün olarak birbiriyle bağlantıl1/muttasıl bir silsile içinde yer aldığını işaret ederek, her bir varlığın, basitten başlayarak durmadan geliştiğini, basitliği azalırken mürekkepliğinin arttığını ve bir üst mertebeye yükseldiğini ifade eder. Bu gelişim süreci insana dek devam eder. Hayy b. Yakzân'da da benzer bir bakış açısı bulunur. Bu anlamda İbn Haldûn, İbn Miskeveyh'in varlığın evrimi düşüncesini, insanın melekût âlemine geçişi, vahiy, peygamberlik ve velâyet kavramlarıla bir araya getirerek derinleştirmiştir. Böylece gayb âlemine hasredilen hakîkat, ilimle, aklî ilkelerle, dil ve mantıkla, sanatla, tekrar içermeyen doğal düşünce ve dolaysız bilinç ile idrak edilebilir. Bunun için insan tüm vehimlerinden uzaklaşıp dolaysız bilinci aracılığıyla Allâh'ın rahmetine sığınmalıdır. Peygamberler ve velilerin doğuştan sahip oldukları bir lütufla temasa geçtikleri gayb âlemine diğer insanlar fitratları gereği ilham ve sezgiyle yaklaşırlar. İşte hak, böylece insanın içinden Allâh'ın yardımıyla doğar. Dolayısıyla İbn Haldûn, yukarıda tasavvuf bahsinde değinilen gaybın bilgisine erişme yollarını ve bir kâmil mürşidin rehberliğini, bu ilkeler bağlamında kabul etmektedir (İbn Haldûn, 2001, Gaybı Bilenler Bölümü; İbn Haldûn, 1988, C.2, İnsanların, Meleklerin ve Peygamberlerin Bilgileri Bölümü).

İbn Haldûn'un evrim sistematiği, varlık evreninde hiyerarşik biçimde yer alan insan dâhil tüm varlıkların evrimleşmesini içerir. Sabit var oluşları bakımından canlı/cansız varlık türlerinin birbirleriyle olan bağları, hiyerarşik ve iletişimsel bir zincirin halkalarını andırır (Uludağ, C.2, 1988, 773). Kimyevî bir iksirle varlıkların değişmesi, başkalaşması ve birbirine dönüşmesi mucizevî değil doğa bilimsel bir faaliyettir. Yoğun bir riyazetle insanın melekler âlemine ittisali ve ilhamlar alması mümkündür, bu konuda peygamberlere has vahiy alma etkinliği dışarıda bırakılırsa, keramet ve kehanet yöntemleri kesinlikleri bakımından birbirine denktir. Devasa tarihî eserlerin meydana getirilişi ise, insanın fiziksel evrimi ile değil, ruhanî gelişimi ile ilgilidir. İbn Haldûn'a göre bu, tek yönlü bir gelişimdir. Darwin'in teorisinde ise evrim gerileme ile ilerlemeyi aynı anda içeren iki yönlü bir harekettir ve melekler âlemi gibi metafizik kavramlara yer verilmez.

Her iki düşünürde de insan hayvanlar âleminin bir üyesidir ve maymun onun aşağ 1 ve yakın komşusudur. Darwin, insanın maymundan geldiği veya onun evrimleşmiş bir türevi olduğu düşüncesini; İbn Haldûn ise insanın evrimi üzerinde coğrafî̀ ve doğal etkilerin önemini vurgular. Örneğin bitki örtüsünün çeşitli, toprakların bol ve bereketli olduğu coğrafyalar, ferdin cesaret ve dayanıklılığını yok eder, nefsanî arzularını körükler ve toplumları atalet ve bireyselliğe sürükler. Kurak ve yaşamanın zor olduğu yerlerde ise insanlar cesur, dayanıklı ve diğerkâm olurlar (İbn Haldûn, 1988, C.1, 393 vd.; Hippokrates, Aristoteles, daha sonra Montesquieu ve Buckle'in benzer düşünceleri için bkz. Dale, 2018, 291; Sezgin, 2008, C.I, 63). Ancak havanın ahlâk ve medeniyet üzerindeki etkisinden söz eden ilk düşünür İbn Haldûn' dur ve düşüncesini özgün kılan yaklaşımlarından biri de budur. Evrim sürecinde coğrafî etkileri büyük oranda reddeden Darwin'e göre ise, canlıların evrimsel değişmeleri ve birbirleriyle olan benzerlik ve farklılıkları tümüyle fiziksel koşullarla açıklanamaz (Darwin, 2012, 129 ve 135). Melekler âlemine geçiş, rüya ve vahiy konuları bağlamında, İbn Haldûn'da ahlâk konusunda insanla hayvan arasında doğrudan ve yakın bir ilişkiden söz edilemez. Bu yaklaşımı da orijinal fakat aynı zamanda indirgemecidir. Buna karşın Darwin, insanın ahlâkî davranış formlarını ve vicdanı içgüdüsel edimler yoluyla hayvandan aldığını ileri sürer. Darwin hayvandan insana evrimi gözetirken, İbn Haldun cansız varlıktan melekelere değin yükselen bir tekâmül yaklaşımını benimser. Böylece 
yalnızca maddî evrendeki varlıkları dikkate alan Darwin'in tersine, maddî olmayan evreni de gözeterek sistemine dâhil eden İbn Haldûn daha tümel bir bakış açısı sergilemektedir. İki düşünür de farklı canlıların birbirlerine evrilme imkânını kabul ederler (Bitkilerin kısıtlı hareket imkânları için bkz. Darwin, 2012, 214).

İbn Haldûn'un evrim fikri, Darwin'den çok Aristoteles'in türlerin evrimi fikrini anımsatır. Aristoteles'e göre her tür kendi içinde maddesinden formuna doğru kapalı bir evrim süreci yaşar, diğer türlerle aralarında bir geçiş bulunmaz. İbn Haldûn'un sosyal evrim düşüncesinde de benzer şekilde, her toplum kendi evrimine sıfırdan başlayarak bedevî ve hadarî umran aşamalarını geçer, potansiyelini en mükemmel şekilde gerçekleştirir ve en son aşamada çözülerek başladığı noktaya döner. Bu süreç kendi içinde döngüseldir/devrî. Toplumsal yaşamın evrimi bakımdan İbn Haldûn ile Darwin arasında da bir benzerlik bulunmaz (Arslan, 2002, 133). İnsanla birlikte tohum, salyangoz, hurma ve maymun gibi bazı varlıkların bu zincir içerisindeki evrimsel yerinin asabiye, tarih, toplum ve umran teorisinden hareketle belirlenmesi, evrimin her tür için mümkün fakat bazı özel türlere has olduğu türünden ilginç sonuçlar doğurmaktadır. İnsanın İbn Haldûn'da yalnızca ruhsal ve aklî, Darwin'de ise fizik temelli evrimi, iki düşünür arasındaki bir başka temel farkı oluşturur.

İbn Haldûn'da insan hayvanlar âlemine dâhil ve onun en gelişmiş formu olduğundan, maymun türleri ile insan arasında bir geçiş ve evrimleşme söz konusu olamaz. Çünkü varlığın evrimi, farklı varlık kuşakları arasındaki evrimleşmeyi içerir. Aynı varlık âleminde yer alan türler arasında ise evrimsel bir geçiş değil birleşme olur. Aynı varlık âlemi içerisinde türlerin karışması ve ortaya her iki türün de özelliklerini üzerinde barındıran yeni ortak varlıkların çıkmasına ağaçların birbirine aşılanması ve eşekle atın birleşerek katırı meydana getirmesi gibi örnekler verilebilir. Bu yeni tür her iki türün de özelliklerini üzerinde taşır ve kendine has bağımsız bir tür olarak varlığını sürdürür. Böylece ancak benzer türler olan insanla maymunun -pek tasavvur edilemese de- birleşmesi sonucunda ortak ve yeni bir türün meydana gelmesinden söz edilebilir. Bu açıdan İbn Haldûn, insanın evrimini umranın sürekliliği içerisinde yorumlar, peygamberlik ve vahiy alma hadisesini, insanın aklî ve ruhî gelişmesi, medenîleşmesi ve toplumun bedevîlikten hadarîliğe geçişi sürecinde bir durak ve üst nokta olarak değerlendirir. Bu bağlamda modern evrim teorilerini kısmen anımsatan düşünceleriyle İbn Haldûn'un Darwin'le ilintilendirilmesi olağandır. Ancak Darwinizmin köklerini İbn Haldûn'dan çok İbn Miskeveyh'te aramak daha doğru olacaktır.

O halde 1) tarihî/toplumsal mânâda insan, zaman içinde fiziksel dönüşüme uğramış, daha büyük bir bedene sahipken daha küçük bir yapıya evrilmiş değildir, eski medeniyetlerden kalan büyük yapıların ortaya çıkabilmesi için, insanın daha büyük olmasına gerek yoktur. Muktedir bir kuvvet olan asabiyyeye dayalı güçlü bir yardımlaşma ve aklî melekelerini kullanarak teknik icatlar yapabilme kabiliyeti, umranın gelişip büyümesi için yeterlidir. 2) Vahiy meleğinin, kendisiyle aynı öze sahip olmayan bir insana vahiy getirmesi, mevcut niteliklerini kısmen kaybederek insanlaşması veya mevcut haliyle insanın melekle iletişim kurabilmesi akla yatkın gelmediğinden, insanın dönüşerek evrimleşmesi ve melekler âlemiyle ittisal etmesi kabule daha şayandır. Böylece insan çeşitli temrinler ve riyazetle melekleşebilir, bu âlemden ilahî hitabı alabilir ve tekrar eski varlığına dönerek tebliğ görevini gerçekleştirebilir. Ancak bu imkânın, akılsal bir yaklaşımla ve sürekli bir yükselişle maymuna has kılınıp kılınamayacağı konusunda bir açıklık yoktur. Zorlama bir yorumla bitkiden hayvana oradan insan doğru ilerleyen zincirvarî evrensel bir bağ ve türler arası ilişki ağı tasavvur edilebilirse de, maymunun fiziksel istidadının sınırı olarak insanı kabul etmek ve melekler âlemine ittisal imkânının yalnızca ve bir takım insanda bulunduğunu kabul etmek daha makul olacaktır.

İnsanın evrimleşmesinin Allâh'a kadar uzanacak bir evrimleşme sürecinin ilahî perdede neden gelişmeye devam etmediğininse iki sebebi olabilir: 1) Tasavvufta dile getirilen vahdet-i vücud düşüncesi ve 2) Fârâbî ve İbn Sînâ çizgisinde gelişen göksel akıllar, On Akı1 Teorisi ve saf akı1 kabul edilen Allâh'ın insan aklı ile kavranması problemleri. Bu iki düşünceye de yakın 
durmayan İbn Haldûn'un, düşüncesini insanın melekleşmesi noktasından öteye götürmemesi ve bu konuda bir açıklamaya yer vermemesi dikkat çekicidir.

\section{Kaynakça}

Akarsu, B. (1975). Felsefe Terimleri Sözlü̆̆̈̈, Ankara: Türk Dil Kurumu Yayınları.

Arslan, A. (2002). İbn Haldûn'un İlim ve Fikir Dünyası, Ankara: Vadi Yayınları.

Arslan, A. (2006). İlkçă̆ Felsefe Tarihi 1 Sokrates Öncesi Yunan Felsefes,. İstanbul: İstanbul Bilgi Üniversitesi Yayınları.

Bayrakdar, M. (2001). İslâm'da Evrimci Yaratılış Teorisi, Ankara: Kitâbiyât Yayınları.

Bayrakdar, M. (2012). Câhız ve Biyolojik Evrimciliğin Doğuşu, (Çev. M. Vural). Kelam Araştırmaları Dergisi; 5(1):117-126.

Dale, S. F. (2018). İbn Haldun ve İnsan Bilimi, (Çev. C. Coşkan, A. Ay). İstanbul: Say Yayınları.

Darwin, Ch. (1994). The Origin of The Moral Sense, Ethics. (ed.Peter Singer). New York: Oxford University Press.

Darwin, Ch. (2009). Descent of Man, Lawrence: Digireads.com Publishing.

Darwin, Ch. (2012). Türlerin Kökeni, (Çev. Ö. Ünalan). İstanbul: Evrensel Basın Yayım.

Demirli, E., (2012). Vahdet-i Vücûd, TDV İslâm Ansiklopedisi, 42, 431-435. İstanbul: Türkiye Diyanet Vakfi.

el-Câbirî, M. Â. (2018). İbn Haldûn'un Düşüncesi-Asabiyet ve Devlet, (Çev. M. Çelik). İstanbul: Mana Yayınları.

el-Husrî, S. (2001). İbn Haldûn Üzerine Araşstrmalar, (Çev. S. Uludağ). İstanbul: Dergâh Yayınları.

Fârâbî. (1951). Vücûbu Sinâ̂tı'l-Kîmîyâ, Belleten, XV, Ankara.

Fromherz, A. J. (2018). İbn Haldûn Hayatı ve Dönemi, (Çev. Y. S. İnanç). İstanbul: Ketebe Yayınevi.

Gazâlî. (2012). İhyâ-i Ulûmi'd-Dîn, (Çev. S. Gülle). 1-4, İstanbul: Huzur Yayınevi.

Gould, S. J. (2002). Darwin ve Sonrası Doğa Tarihi Üzerine Düşünceler, (Çev. C. Temürcü). Ankara: TÜBİTAK.

Hassan, Ü. (1977). İbn Haldûn'un Metodu ve Siyaset Teorisi, İstanbul: Sevinç Matbaası.

Hawi, S. S. (2003). İslâmî Naturalist Bir Düşünce Olarak Abiogenesis-İbn Tufeyl'in Görüşleri, (Çev. Orhan Düz). Hayy b. Yakzân. 254-279. İstanbul: İnsan Yayınları.

İbn Haldûn. (1988). Mukaddime, (Çev. S. Uludağ). 1-2, İstanbul: Dergâh Yayınları.

İbn Haldûn. (1998). Şifâu's-Sâil li Tezhîbi’l-Mesâil-Tasavvufun Mahiyeti, (Çev. S. Uludağ). İstanbul: Dergâh Yayınları.

İbn Haldûn. (1998-99). Tarihu'l-Allâme İbn Haldûn. tedkîk Muhammed b. Tâvît el-Tancî, Kâhire/Beyrût: el-Mucellidu'r-Râbi“ 'Așer, Dâru'l-Kitâbu'l-Masrî/el-Lübnânî, H.1418-19.

İbn Haldûn. (2001). Mukaddime, (Tashih ve haz. H. Şehâde, S. Zekâr). Beyrut: Dâru'l-Fikr, H.1431.

İbn Haldûn. (2011). Bilim ile Siyaset Arasında Hatıralar, (Çev. V. Akyüz). İstanbul: Dergâh Yayınları. 
İbn Haldûn. (2015). Mukaddime, (Çev. Cevdet Paşa). haz. Yavuz Yıldırım, Sami Erdem, Halit Özkan ve M. Cüneyt Kaya, İstanbul: Türkiye Yazma Eserler Kurumu Başkanlığı.

İbn Miskeveyh. (2014). Küçük Başar1-el-Fevzu'l-Asğar, (Çev. M. Kaya). İslâm Filozoflarından Felsefe Metinleri, İstanbul: Klasik Yayınları.

İbn Sînâ ve Kîmîyâ, Ankara Üniversitesi İlâhiyât Fakültesi Dergisi, IV, Ankara, 1952.

İbn Tufeyl-İbn Sînâ. (2003). Hayy b. Yakzân, (Çev. Yusuf Özkan Özburun, Serkan Özburun, Derya Örs vd.). İstanbul: İnsan Yayınları.

İhvân-1 Safâ. (2012). İhvân-ı Safâ Risâleleri, (Çev. A. Kahraman, A. Durusoy, M. Özdemir vd.). C.1-5, İstanbul: Ayrıntı Kitabevi.

Kâtip Çelebi. (2007). Keşfu'z-Zunûn An Esâmi'l-Kutubî ve'l-Funûn, C.I-I. (Çev. R. Balcı). İstanbul: Tarih Vakfı Yurt Yayınları.

Kütüb-i Sitte Tercüme ve Şerhi, (2014). (Haz. İ. Canan). C.1-18, Ankara: Akçağ Yayınevi.

Mevlânâ. (1990). Mesnevî Tercemesi ve Şerhi, (Haz. A. Gölpınarl1). 1-6, İstanbul: İnkılap Yayınevi.

Özel, İ. (1992). Üç Mesele, İstanbul: Çıdam Yayınları.

Özel, İ. (2017). Erbain Kırk Yılın Şiirleri, İstanbul: Tiyo Yayınları.

Sezgin, F. (2008). İslam'da Bilim ve Teknik, 5 (Çev. A. Aliy). İstanbul: İstanbul Büyükşehir Belediyesi Kültür A.Ş.

Tomar, C. (2006). Mit ile Gerçek Arasında: Arap Dünyasında İbn Haldun Yaklaşımları, İslâm Araştırmaları Dergisi, (16): 1-26.

Torun, T. (2014). Darwin'in Evrim Teorisinde Ahlâkın Kökeni, İstanbul Üniversitesi Illahiyat Fakültesi Dergisi, (30).

Yakıt, İ. (1984). Darwin'den Önce İslâm Düşünürlerinde Evrimle İlgili Fikirler, Felsefe Arkivi; (24): 101-122. 